\title{
Ryanodine Receptors: Structure, Expression, Molecular Details, and Function in Calcium Release
}

\author{
Johanna T. Lanner, Dimitra K. Georgiou, Aditya D. Joshi, and Susan L. Hamilton \\ Baylor College of Medicine, Department of Molecular Physiology and Biophysics, Houston, Texas 77030 \\ Correspondence: susanh@bcm.edu
}

Ryanodine receptors (RyRs) are located in the sarcoplasmic/endoplasmic reticulum membrane and are responsible for the release of $\mathrm{Ca}^{2+}$ from intracellular stores during excitation-contraction coupling in both cardiac and skeletal muscle. RyRs are the largest known ion channels (>2MDa) and exist as three mammalian isoforms (RyR $1-3$ ), all of which are homotetrameric proteins that interact with and are regulated by phosphorylation, redox modifications, and a variety of small proteins and ions. Most RyR channel modulators interact with the large cytoplasmic domain whereas the carboxy-terminal portion of the protein forms the ion-conducting pore. Mutations in RyR2 are associated with human disorders such as catecholaminergic polymorphic ventricular tachycardia whereas mutations in RyR1 underlie diseases such as central core disease and malignant hyperthermia. This chapter examines the current concepts of the structure, function and regulation of RyRs and assesses the current state of understanding of their roles in associated disorders.

ntracellular $\mathrm{Ca}^{2+}$ is an important secondary messenger for signal transduction and is essential for cellular processes such as excitationcontraction coupling (E-C coupling). The major source of intracellular $\mathrm{Ca}^{2+}$ is the sarcoplasmic reticulum (SR) in striated muscle and the endoplasmic reticulum (ER) in other cell types. There are two major $\mathrm{Ca}^{2+}$ release channels localized in the SR/ER, the ryanodine receptors (RyRs) (Otsu et al. 1990) and inositol 1,4,5-triphosphate receptors ( $\mathrm{IP}_{3} \mathrm{Rs}$ ) (Nixon et al. 1994). The present article reviews the structure, regulation, expression, and function of the RyRs. RyRs exist in three isoforms (RyR 1-3) and are named after the plant alkaloid ryanodine, which binds to RyRs with high affinity and specificity and displays preferential interactions with the open state of the channel allowing its usage to evaluate the functional state of the channel (Imagawa et al. 1987; Inui et al. 1987; Lai et al. 1988; Chu et al. 1990). Ryanodine at nanomole concentrations locks the channel in an open subconductance state and inhibits the channel at high concentrations (>100 $\mu \mathrm{M})$ (Meissner et al. 1986; Lai et al. 1989; McGrew et al. 1989). RyRs are homotetamers with a total molecular mass of $>2 \mathrm{MDa}$ (each subunit is $>550 \mathrm{kDa}$ ) (Inui et al. 1987; Lai et al. 1988). RyRs are modulated (see Fig. 1) directly or indirectly by the dihydropyridine receptor

Editors: Martin D. Bootman, Michael J. Berridge, James W. Putney, and H. Llewelyn Roderick Additional Perspectives on Calcium Signaling available at www.cshperspectives.org

Copyright (C) 2010 Cold Spring Harbor Laboratory Press; all rights reserved; doi: 10.1101/cshperspect.a003996

Cite this article as Cold Spring Harb Perspect Biol 2010;2:a003996 
J.T. Lanner et al.
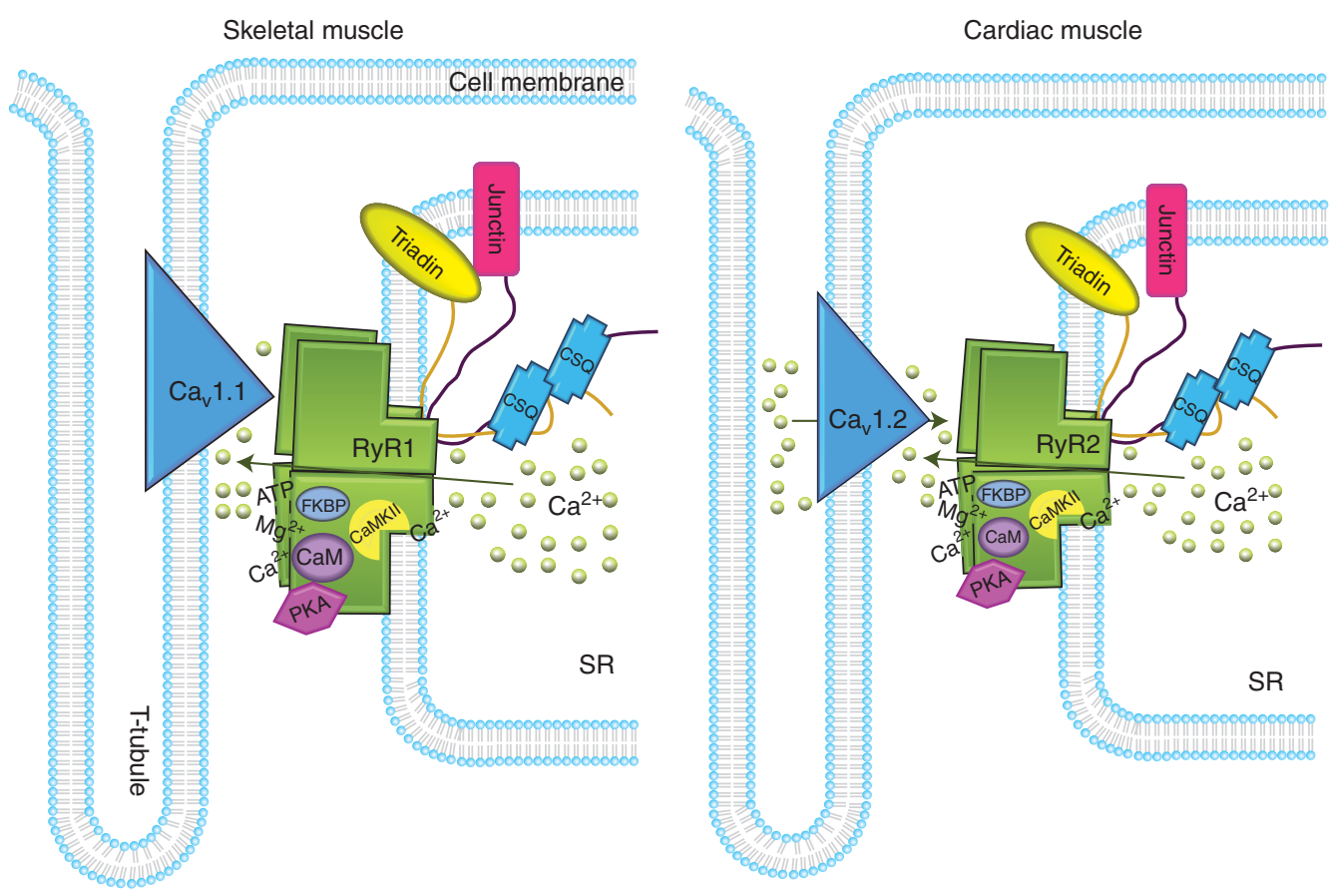

Figure 1. Schematic figure of the interaction between RyR and various modulators. Left panel illustrates skeletal muscle and right panel shows cardiac muscle. Modulators bind to the RyR tetramer but are for simplicity only depicted on one monomer.

(DHPR; also known as L-type $\mathrm{Ca}^{2+}$ channel, $\left.\mathrm{Ca}_{\mathrm{V}} 1.1 / 1.2\right)$ and by various ions, small molecules and proteins, e.g., $\mathrm{Ca}^{2+}, \mathrm{Mg}^{2+}$, protein kinase A (PKA), FK506 binding proteins (FKBP12 and 12.6), calmodulin (CaM), $\mathrm{Ca}^{2+} /$ calmodulin-dependent protein kinase II (CaMKII), calsequestrin (CSQ), triadin, junctin (Smith 1986; Tanabe et al. 1990; Ikemoto et al. 1991; Sabbadini et al. 1992; Wang and Best 1992; Brillantes et al. 1994; Chen and MacLennan 1994; Yang et al. 1994; Ma et al. 1995; Mayrleitner et al. 1995; Tripathy et al. 1995; Timerman et al. 1996; Nakai et al. 1998; Moore et al. 1999b; Rodney et al. 2000). RyR1 and RyR2 are crucial for E-C coupling in both skeletal and cardiac muscle, respectively. The action potential travels to transverse tubules (t-tubules) resulting in SR $\mathrm{Ca}^{2+}$ release, either by mechanical coupling to DHPR in skeletal muscle (Rios and Brum 1987) or by $\mathrm{Ca}^{2+}$ induced $\mathrm{Ca}^{2+}$ release in cardiac muscle (Endo 1977). Increases in cytoplasmic $\mathrm{Ca}^{2+}$ initiate muscle contraction. $\mathrm{Ca}^{2+}$ is then pumped back to the SR by sarcoplasmic reticulum $\mathrm{Ca}^{2+}$
ATPase (SERCA) leading to relaxation (Nakai et al. 1998; Fill and Copello 2002). RyRs also play important roles in signal transduction in the nervous system and in osteoclasts where they contribute to secretion, synaptic plasticity, learning, and apoptosis (Zaidi et al. 1992; Chavis et al. 1996; Schwab et al. 2001).

\section{RYANODINE RECEPTOR GENES AND ISOFORMS}

There are three known mammalian isoforms of RyR: RyR1, RyR2, and RyR3. RyR1 was first detected in skeletal muscle (Takeshima et al. 1989; Zorzato et al. 1990), RyR2 was first found in cardiac muscles (Nakai et al. 1990; Otsu et al. 1990), and RyR3, previously referred to as the brain isoform, was found in brain (Hakamata et al. 1992). RyR1 is the most thoroughly examined isoform because of its high expression levels and ease of purification from skeletal muscle. In humans, the gene encoding RyR1 is located on chromosome 19q13.2 and spans 104 exons. 
The gene encoding RyR2 is located on chromosome 1q43 and spans 102 exons, whereas the RyR3 gene with 103 exons is on chromosome 15q13.3-14. RyR1, 2, and 3 are located in chromosomes 7A3, 13A2, and 2E4 in mice (Mattei et al. 1994). In nonmammalian vertebrates $\operatorname{Ry} R \alpha$ and $\operatorname{RyR} \beta$ are highly homologous to the three mammalian isoforms (Oyamada et al. 1994; Ottini et al. 1996). RyRs have been identified in Drosophila (D) melanigaster, Caenorhabditis (C) elegans, and Homarus americanus (Takeshima et al. 1994; Maryon et al. 1996; Quinn et al. 1998). The three mammalian isoforms are 65\% identical in sequence (Hakamata et al. 1992) with three major regions of diversity: D1, between residues 4254 and 4631 in skeletal sequence and 4210 and 4562 in cardiac sequence; D2 between residues 1342 and 1403 in skeletal sequence and residues 1353 and 1397 in the cardiac sequence; D3, between residues 1872 and 1923 in skeletal sequence and 1852 and 1890 in the cardiac sequence. Region D2 is critical for the mechanical interaction between RyR1 and $\mathrm{Ca}_{\mathrm{V}} 1.1$ (Perez et al. 2003) and mutations in D1 alter $\mathrm{Ca}^{2+}$ and caffeine sensitivity of RyR1 (Du et al. 2000). D3 may contain $\mathrm{Ca}^{2+}$ dependent inactivation sites (Hayek et al. 1999). In addition to these diverse regions, the large cytoplasmic domain is the site of both interaction with a large number of the modulators of channel activity, and many of the mutations that underlie the RyR channelopathies. Four-fifths of the RyR protein is cytoplasmic with $\sim$ one-fifth luminal and membrane spanning domains.

\section{EXPRESSION OF RYANODINE RECEPTORS}

The RyR1 isoform is primarily expressed in skeletal muscles (Takeshima et al. 1989; Zorzato et al. 1990) and is located in the junctional region of the terminal SR (Franzini-Armstrong and Nunzi 1983). RyR1 also appears to be expressed at low levels in cardiac muscle, smooth muscle (Neylon et al. 1995), stomach, kidney, thymus (Nakai et al. 1990; Giannini et al. 1995), cerebellum, Purkinje cells, adrenal glands, ovaries, and testis (Marks et al. 1989; Takeshima et al. 1989; Furuichi et al. 1994; Ottini et al. 1996). Recently it has been shown that RyR1 is also expressed in B-lymphocytes (Vukcevic et al. 2010).

The predominant form of RyR in cardiac muscle is RyR2 (Nakai et al. 1990; Otsu et al. 1990). Recently a splice variant of RyR2 was identified in the heart that increases susceptibility to apoptosis (Valdivia 2007). RyR2 is also expressed at high levels in Purkinje cells of cerebellum and cerebral cortex (Lai et al. 1992; Nakanishi et al. 1992; Sharp et al. 1993; Furuichi et al. 1994) and in low levels in stomach, kidney, adrenal glands, ovaries, thymus, and lungs (Kuwajima et al. 1992; Giannini et al. 1995).

RyR3 is expressed in hippocampal neurons, thalamus, Purkinje cells, corpus striatum (Hakamata et al. 1992; Lai et al. 1992; Furuichi et al. 1994), skeletal muscles (highest expression in the diaphragm) (Neylon et al. 1995; Marks et al. 1989), the smooth muscle cells of the coronary vasculature, lung, kidney, ileum, jejunum, spleen, stomach of mouse and aorta, uterus, ureter, urinary bladder, and esophagus of rabbit (Giannini et al. 1992; Hakamata et al. 1992; Giannini et al. 1995; Ottini et al. 1996).

Nonmammalian vertebrates, such as birds, fish, and chickens express isoforms $\operatorname{RyR} \alpha$ and $\beta$ (O'Brien et al. 1993). RyR $\alpha$ is abundant in skeletal muscles and its expression is lower in brain (cerebellum) (Oyamada et al. 1994). $\operatorname{RyR} \beta$ is expressed in various tissues including skeletal and cardiac muscles, cerebellum, lungs, and stomach (Oyamada et al. 1994). In C. elegans RyRs are found in body wall, vulval, anal, and pharyngeal muscles (Hamada et al. 2002). In $D$. melanogaster a single isoform of $\mathrm{RyR}$ is expressed in digestive tract and nervous system (Vazquez-Martinez et al. 2003).

\section{ROLE OF RYANODINE RECEPTORS IN HUMAN DISEASES}

Mutations in both RyR1 and RyR2 are associated with a number of human diseases. Mutations in the RYR1 gene underlie several debilitating and/or life-threatening muscle diseases including malignant hyperthermia $(\mathrm{MH})$ (MacLennan et al. 1990), heat/exercise induced exertional rhabdomyolysis (Capacchione et al. 2010), central core disease (CCD) (Zhang et al. 
J.T. Lanner et al.

1993), multiminicore disease (MmD) (Ferreiro et al. 2002), and atypical periodic paralyses (APP) (Zhou et al. 2010). Mutations in RyR2 cause/are associated with catecholaminergic polymorphic ventricular tachycardia (CPVT) and arrhythmogenic right ventricular dysplasia type 2 (ARVD2) (Phillips et al. 1994, Zhang et al. 1993, Magee et al. 1956). Today around 300 mutations have been identified and linked to diseases associated with RyR (Fig. 2).

$\mathrm{MH}$ is an autosomal dominant disease in which genetically susceptible individuals respond to inhalation anesthetics (e.g., halothane) and muscle relaxants (e.g., succinylcholine) with sustained muscle contractions (Mickelson and Louis 1996). More than 150 different point mutations in the RYR1 gene have been identified and linked to $\mathrm{MH}$ (Fig. 2). The majority of RyR1 mutations linked to $\mathrm{MH}$ cluster in the cytoplasmic domains of RyR1 (amino acids 35 to 614 and 2129 to 2458). Another cluster of mutations is found near the carboxyl terminus (4637 to 4973) (Phillips et al. 1994; Quane et al.
1994; Lynch et al. 1999; Monnier et al. 2000; Scacheri et al. 2000; Tilgen et al. 2001). MH is often a silent disorder that goes undetected until the patient undergoes surgery or is exposed to high ambient temperatures $\left(\sim 37^{\circ} \mathrm{C}\right)$ (JurkatRoth et al. 2000). The underlying physiological consequence of $\mathrm{MH}$ is abnormal calcium homeostasis with increase sensitivity of channel opening in response to activators (Tong et al. 1999).

An $\mathrm{MH}$ episode is characterized by elevations in body temperature, metabolic acidosis, hypoxia, tachycardia, skeletal muscle rigidity, and rhabdomyolysis (Denborough et al. 1962; Ellis et al. 1988; Pamukcoglu 1988; Britt et al. 1991; Ryan and Tedeschi 1997) and is life threatening if not immediately treated with dantrolene, currently the only clinically approved treatment for $\mathrm{MH}$ (Ward et al. 1986; Zhao et al. 2001; Paul-Pletzer et al. 2002). The incidence of $\mathrm{MH}$ is $\sim 1$ in 15,000 anesthetized children and $\sim 1$ in 50,000 to 100,000 anesthetized adults (MacLennan 1992; Strazis and Fox 1993; Rosenberg et al. 2007). Another disorder related

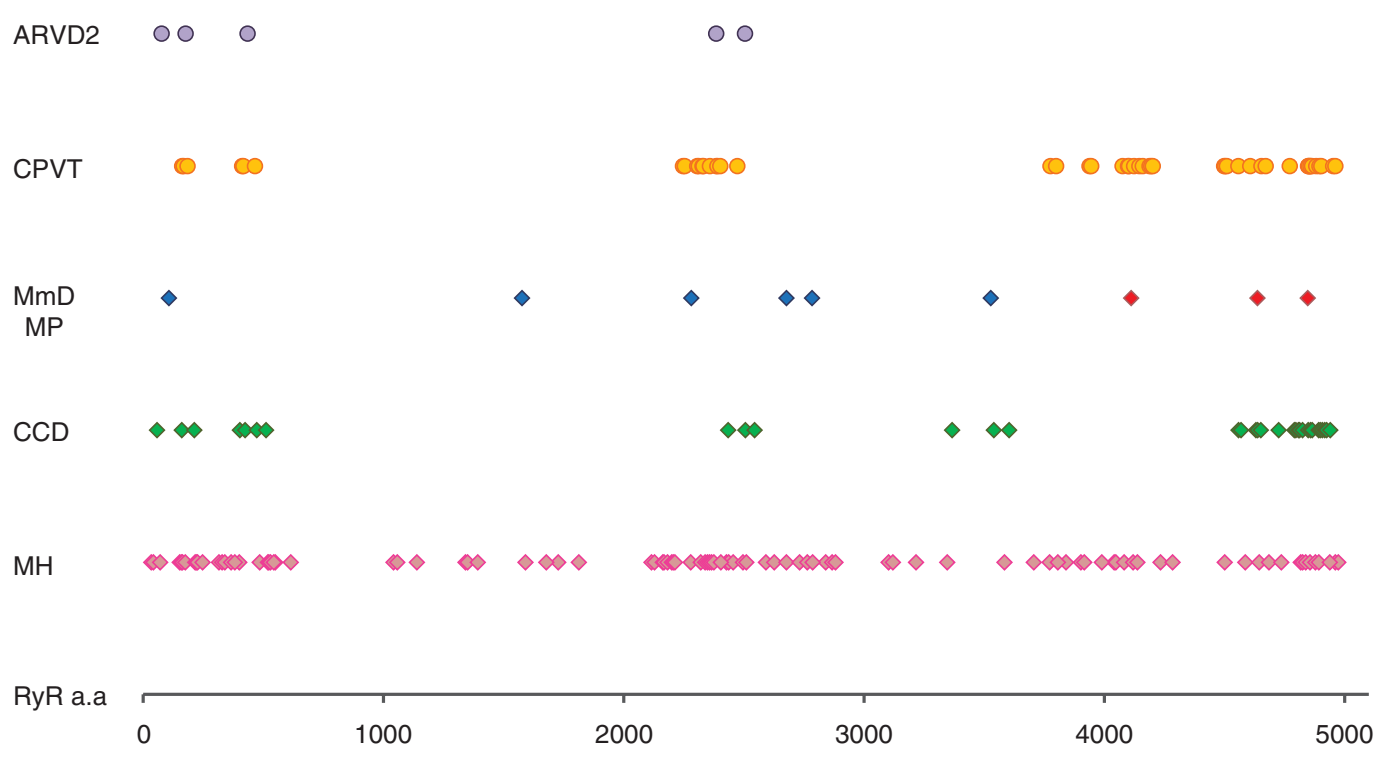

Figure 2. Linear presentation of RyR primary sequence outlining known mutations associated with skeletal and cardiac muscle diseases. Diamond shaped dots represent RyR1 mutations associated with: MH (151 mutations), CCD (63 mutations), and MmD (blue, 6 mutations) or other myopathies (MP, red, 4 mutations). Circles represent RyR2 mutations associated with: CPVT (53 mutations) and ARVD2 (5 mutations). Data collected from HGMD® (database of human gene mutation data) until 2006, UniProt 2007-2009, and publication by Vukcevic et al. 2010). 
to $\mathrm{MH}$ is heat/exercise-induced exertional rhabdomyolysis; a clinical syndrome where heat/ exercise-induced triggers breakdown of striated muscles that results in renal failure, hyperkalemia, and multi-organ failure. Approximately 26,000 cases are identified per year in United States (Capacchione et al. 2010).

CCD is a congenital myopathy in humans, and is characterized by hypotonia and muscle weakness of lower extremities leading to delayed attainment of motor skills (Dirksen and Avila 2002; Lueck and Dirksen 2004; Robinson et al. 2006). Slow-twitch (type I) skeletal muscles (e.g., soleus) of CCD of patients exhibit amorphous areas (central cores) that lack mitochondria and oxidative enzyme activity (Magee and Shy 1956; Shuaib et al. 1987). In some cases SR and t-tubules also degenerate and resting $\mathrm{Ca}^{2+}$ concentrations elevate with or without luminal store depletion (Tong et al. 1999). The majority of CCD causing mutations are in the pore-forming domain of RyR1 (Lynch et al. 1999; Monnier et al. 2000; Scacheri et al. 2000; Tilgen et al. 2001). Incidence of CCD is $\sim 1$ in 16,000 of total congenital myopathies and $\sim 1$ in 100,000 live births (Jungbluth 2007a).

$\mathrm{MmD}$ is an autosomal recessive myopathy characterized by weakness in axial and proximal limb muscles, hypoxia, and muscle biopsies showing characteristic mini cores due to lack of oxidative enzyme activity (Jungbluth 2007b; Sharma et al. 2007).

APP are dominant and genetically heterogeneous conditions characterized by muscle weakness and are divided into hypokalemic periodic paralysis and hyperkalemic periodic paralysis. Mutations on SCN4A and CASNAS1S gene that codes for $\alpha 1$ s subunit of DHPR have been identified as general cause of hypokalemic- and hyperkalemic-periodic paralysis, respectively. Recently in a patient suffering from MmD the RyR1 mutation Arg2939Lys has been identified and clinical features of the patient are reminiscent of hyperkalemic periodic paralysis, suggesting a new RyR1-related form of periodic paralysis with additional myopathy features (Zhou et al. 2010).

Mutations in RyR2 produce altered $\mathrm{Ca}^{2+}$ homeostasis leading to ARVD2 (Dalla Volta et al. 1961; Marcus et al. 1982; Fontaine et al. 1984) and CPVT (Marks et al. 2002; Priori et al. 2002; Laitinen et al. 2003). ARVD2 an autosomal dominant cardiac disease characterized by replacement of myocytes with fibrofatty tissue leading to ventricular arrhythmias (Corrado et al. 2000). Mutations in RyR2 are detected at three regions that are homologous to the mutations on RyR1 associated with $\mathrm{MH}$ and CCD. Studies in ARVD2 suggest that $\mathrm{Ca}^{2+}$ leakage from myocardial SR via dysfunctional RyR2 is associated with development of ventricular arrhythmias (Tiso et al. 2001). The incidence of ARVD2 is $\sim 1$ in 10,000 adults in United States (Fontaine et al. 2001). CPVT is characterized by stress-induced ventricular tachycardia (Marks et al. 2002; Priori et al. 2002; Laitinen et al. 2003). Roles for protein kinase A (PKA) and $\mathrm{Ca}^{2+} /$ calmodulin dependent protein kinase II (CaMKII) phosphorylation and enhancement of RyR2 open probability in these arrhythmias has been suggested (Valdivia et al. 1995; Marx et al. 2000; Wehrens et al. 2004). In single channel recordings it has been shown that CPVT RyR2 mutation Arg4496Cys increases open probability at low $\mathrm{Ca}^{2+}$ concentrations $(\sim 5 \mathrm{nM})$ but not at higher concentrations $(\sim 150 \mathrm{nM})$ (Jiang et al. 2002; Wehrens and Marks 2003). In patients with CPVT increased PKA phosphorylation and leaky RyR2 channels was observed during $\beta$-adrenergic stress and exercise. Binding studies in vitro suggested that the mutant RyR2 associated with CPVT have lower affinity for FKBP12.6 (Wehrens et al. 2003). Later studies suggested that CPVT RyR2 expressing cells are more sensitive to $\beta$-adrenergic receptor stimulation (by either isoproterenol or forskolin) and have prolonged $\mathrm{Ca}^{2+}$ transients under these conditions. This sensitivity does not appear to be caused by differences either in RyR2 phosphorylation or loss of FKBP12.6 (George et al. 2003). Nonsense or missense mutations in the calsequestrin 2 gene have also been associated with autosomal recessive form of CPVT (Lahat et al. 2001; Postma et al. 2002).

RyR3 is the least studied ryanodine receptor, and consequently little is known of its function. Recently, RyR3 was suggested to play a role 
J.T. Lanner et al.

in Alzheimer's disease, and up-regulation of RyR3 in cortical neurons is neuroprotective in TgCRND8 mouse model of Alzheimer's disease (Supnet et al. 2009).

\section{ULTRASTRUCTURAL STUDIES ON RYANODINE RECEPTOR}

\section{The Size Challenge}

RyRs, the largest known ion channels (Takeshima et al. 1989; Nakai et al. 1990; Otsu et al. 1990; Zorzato et al. 1990; Hakamata et al. 1992), are large conductance channels (Smith et al. 1985; Smith et al. 1986b) capable of creating rapid transient increases of cytosolic $\mathrm{Ca}^{2+}$. Analysis of the primary structure of RyRs reveals several functional motifs seen in other proteins; but the role of these motifs in RyRs function has not yet been elucidated (see review Hamilton and Serysheva 2009). The importance of RyRs in mammalian physiology and disease drives the need for high resolution structural information. The massive size, multiple modulators, and the dynamic nature of RyRs make their structural analysis a challenge. Advances in single-particle electron cryomicroscopy (cryoEM) and crystal structures of small fragments ( $\sim 200$ amino acids) of the protein (Amador 2009; Lobo and Van Petegem 2009) are beginning to elucidate many important structural features.

\section{Structural Studies on RyRs}

Most cryo-EM studies on RyRs, (Radermacher et al. 1992; Radermacher et al. 1994; Serysheva et al. 1995; Orlova et al. 1996; Sharma et al. 1998; Serysheva et al. 1999; Benacquista et al. 2000; Sharma et al. 2000; Ludtke et al. 2005; Samsó et al. 2005; Serysheva et al. 2005; Serysheva et al. 2008; Samsó et al. 2009) and all the subnanometer resolution analysis (Serysheva et al. 2008; Samsó et al. 2009) have focused on the RyR1, however, some progress has been made with RyR2 (Sharma et al. 1998; Liu et al. 2002) and RyR3 (Sharma et al. 2000; Liu et al. 2001). Overall, the structures of all three isoforms are similar, consistent with the high sequence homology $(\sim 65 \%)$. However, the small differences seen are important, because they reflect variations in the primary sequence and are likely to be related to the specialized functions of each isoform.

RyRs form homotetramers of square prism shape and are arrayed in the SR where they control the release of $\mathrm{Ca}^{2+}$. The cytoplasmic area of the channel $(280 \AA \times 280 \AA \times 120 \AA)$ is connected with the transmembrane region (120 $\mathrm{A} \times 120 \AA \times 60 \AA$ ) (Fig. 3). The membrane region constitutes approximately onefifth of the channel and is localized to the carboxy terminal of the protein and forms the ionconducting pore. The cytoplasmic/sarcoplasmic area that is also called the "foot" is a huge area with cavities and micro-structures that facilitate interactions with solvent, small molecules, and protein modulators. The corners of the cytoplasmic area, also called "clamps" are connected through the "handle" domain that surrounds the "central rim" domain of the cytoplasmic area. This area is connected to the membrane region through the "column." These structural domains have been divided in to 15 subdomains. The clamps (Fig. 3, subdomains $5,6,7,8,9,10)$ undergo major conformational changes during the opening and closing of the channel (Serysheva et al. 2008; Samsó et al. 2009), are likely to participate in intermolecular interactions with neighboring RyRs, and are the sites of interactions with modulators (Wagenknecht et al. 1994; Wagenknecht et al. 1996; Wagenknecht et al. 1997; Samsó and Wagenknecht 2002; Samsó et al. 2006; Sharma et al. 2006; Meng et al. 2009). Two of the areas of high divergence in the primary sequence of the RyR isoforms were mapped in the clamps (Zhang et al. 2003; Liu et al. 2004). At subnanometer resolution seven $\alpha$-helixes and three $\beta$-sheets have been localized to the clamp domain (Serysheva et al. 2008).

The handle domain that is formed by subdomains 3 and 4 (Fig. 3 ) has been found to contain an expanded region of divergence (Liu et al. 2002 ), and a $\beta$-sheet mapped on the subdomain 4 (Serysheva et al. 2008). In total seven $\beta$ sheets and $36 \alpha$-helixes at various orientations have been mapped on the cytoplasmic region 
A

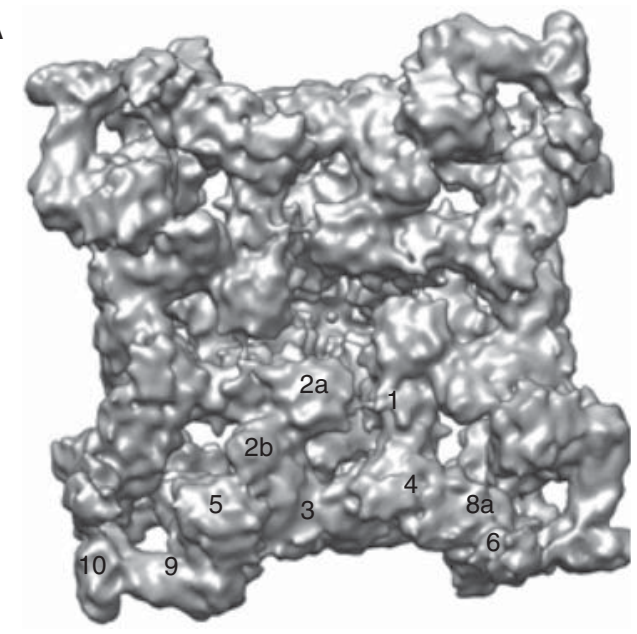

B

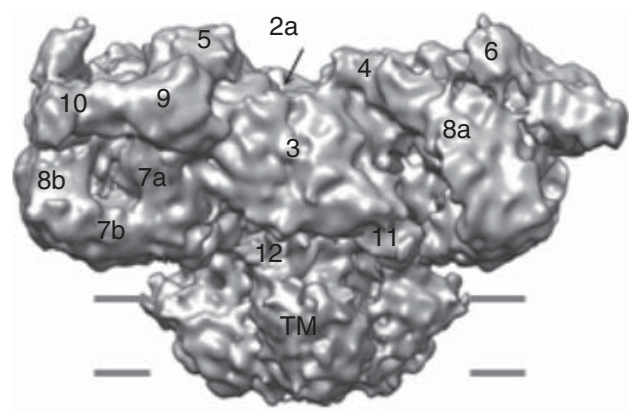

Figure 3. Cryo-EM reconstruction of RyR1 at $9.6 \AA$ resolution. Cytoplasmic domain $(A)$ and side view $(B)$ of RyR1 with the different subdomains mapped by Irina Serysheva (See section "structural studies" for detailed information).

of the channel (Serysheva et al. 2008). These structures appear interconnected and merge toward the center of the molecule (Samsó et al. 2005). Two more $\beta$-sheets have been found in central rim (Fig. 3, subdomains 1,2) and one in the column (Fig. 3, subdomains 11,12), which also has eight $\alpha$-helixes (Serysheva et al. 2008) that maintain the connection of the cytoplasmic and transmembrane regions (Samsó et al. 2005).

Current three-dimensional reconstructions at 8-10 ̊ resolution suggest five (Ludtke et al. 2005; Serysheva et al. 2008) or six $\alpha$-helixes (Samsó et al. 2005) with different orientation in the transmembrane region of the closed channel. Although these studies (Ludtke et al. 2005; Samsó et al. 2005) were performed at similar conditions, they differ in interpretations, one study suggesting conformational similarity to the open $\mathrm{K}^{+}$channel (Ludtke et al. 2005) and the other suggesting a structure more similar to the closed $\mathrm{K}^{+}$channel (Samsó et al. 2005; Samsó et al. 2009). The conformation of the open RyR has so far only been proposed to resemble the conformation of the open $\mathrm{K}^{+}$ channel (Samsó et al. 2009). The pore region has been predicted to consist of between 4 and 12 transmembrane segments (Takeshima et al. 1989; Zorzato et al. 1990; Tunwell et al. 1996;
Du et al. 2002). Most of these models place both amino- and carboxy-termini in the cytoplasm. The ion conducting pore has been proposed to be located in the lumenal region and to include the GVRAGGGIGD amino acid sequence (4891-4900 human RyR1) (Zhao et al. 1999; Du et al. 2001) which is conserved between RyRs. The sequence GGIG has been proposed as the selectivity filter (Balshaw et al. 1999; Gao et al. 2000) based on the similarity with the consensus selectivity filter of $\mathrm{K}^{+}$channels. During channel opening, massive movements of cytoplasmic and transmembrane masses take place and result in a $4 \AA$ increase of the ion gate (Samsó et al. 2009).

\section{Crystal Structure of the Amino-Terminal Domain}

The first crystal structures of RyRs are from the amino-terminal domain. The first 210 amino acids of the RyR1 structure (rabbit) was at $2.5 \AA$ resolution (PDB ID code 3HSM) (Amador 2009), and a similar fragment (amino acids 9-205 of rabbit RyR1) was resolved at $2.9 \AA$ resolution (PDB ID code 3ILA) (Lobo and Van Petegem 2009). The structure of the first 217 amino acids of mouse RyR2 was at $2.5 \AA$ resolution (PDB ID code 3IM5) (Lobo and 
J.T. Lanner et al.

Van Petegem 2009). These domains of RyR1 and RyR2 display the same overall fold, and consist of a $\beta$-trefoil domain flanked by a rigid $\alpha$-helix. Furthermore, minor differences are seen in the loops connecting the various $\beta$-strands in the two isoforms (Amador 2009; Lobo and Van Petegem 2009).

\section{Effects of Disease-Causing Mutations on the Structure of RyR1}

An area rich in disease-associated mutations has been identified in the amino-terminal domain of RyR1 where mutations associated with $\mathrm{MH}$ and CCD have been located. Six are in a short loop between Gln156 and Asp167, and the rest either in different $\beta$-strands (Cys35, Arg178, and Tyr179) or loops (Leu14 and Arg45) (Amador 2009). Similar clustering of disease-causing mutations is seen in RyR2. Mutations found in RyR2 associated with CPVT and ARVD2, Arg169, and Arg176 (which correspond to Arg156 and Arg163 MH mutations of RyR1) are in a short loop with Pro164. Two more disease-causing mutations, Ala77 and Val186, are located in the rigid $\alpha$-helix and in a small loop close to a $\beta$-strand, respectively (Lobo and Van Petegem 2009). These mutations in the amino-terminal of RyRs have been proposed to affect the interaction of RyR1 with modulators because they appear to cause only local changes in the structure (Amador 2009; Lobo and Van Petegem 2009). Another area of the aminoterminal region, amino acids 414-466 of RyR2 contains more than half of the amino-terminal mutations associated with cardiac arrhythmias and sudden death (Wang et al. 2007) and was mapped to a location between subdomains 5 and 9 using green fluorescent protein insertion into the primary structure and difference mapping of cryo-EM reconstructed structures (Wang et al. 2007). Notably, mutations at positions Glu161, Arg164, Arg402, and Ile404 of RyR1 and the mutations Arg169, Ile417, and Arg418 of RyR2 are located in the suggested FKBP binding pocket (Serysheva et al. 2008); whereas the Ile4898Thr CCD mutation appears to be located in the proposed selectivity filter in the pore region.

\section{RYR REGULATION}

RyRs, together with $\mathrm{Ca}_{\mathrm{v}} 1.1 / \mathrm{Ca}_{\mathrm{v}} 1.2$, PKA, FKBP12 and 12.6, CaM, CaMKII, triadin, junction, and calsequestrin form the core of the macromolecular complex that regulates $\mathrm{SR} \mathrm{Ca}^{2+}$ release. Thus, RyR structure, function and regulation are likely to be defined within this complex macromolecular set of interactions. Despite the $\sim 65 \%$ sequence homology, the different RyR isoforms respond differently to some modulators. Most of the RyRs modulators interact with the cytoplasmic region of the channel, suggesting that they allosterically regulate channel gating. The locations of the binding sites for some of the modulators have been predicted from the primary structure, interactions with RyR1 fragments, and from difference mapping in the cryo-EM structures.

\section{$\mathrm{Ca}_{\mathrm{v}} 1.1$ and 1.2}

The voltage dependent $\mathrm{Ca}^{2+}$ channels $\left(\mathrm{Ca}_{\mathrm{V}} 1.1\right.$ and $\mathrm{Ca}_{\mathrm{V}} 1.2$, skeletal and cardiac isoforms respectively), also known as dihydropyridine receptors (DHPRs), are composed of multiple subunits: $\alpha_{1}, \alpha_{2} / \delta, \beta$ and $\gamma$ for $\mathrm{Ca}_{V} 1.1$. $\mathrm{Ca}_{V} 1.2$ has $\alpha_{1}, \alpha_{2} / \delta$, and $\beta$ but the $\gamma$ subunit has not been identified. The $\alpha_{1}$ subunit is both the voltage sensing and the pore forming subunit. DHPRs and RyRs are targeted to either side of the narrow junctional gap that separates the external and internal membrane systems in striated muscle. They are arranged so that bidirectional structural and functional coupling can occur between the proteins. The molecular mechanism of E-C coupling is fundamentally different between skeletal and cardiac muscle (Rios and Brum 1987; Bers and Stiffel 1993; Garcia et al. 1994; Lamb 2000). In skeletal muscle a physical interaction between $\mathrm{Ca}_{\mathrm{v}} 1.1$ and RyR1 is required for E-C coupling and SR $\mathrm{Ca}^{2+}$ release; referred to as voltage-induced $\mathrm{Ca}^{2+}$ release (Lamb 2000). In contrast, RyR2 $\mathrm{Ca}^{2+}$ release in cardiac muscle is initiated by $\mathrm{Ca}^{2+}$ influx via $\mathrm{Ca}_{v} 1.2$, designated $\mathrm{Ca}^{2+}$ induced $\mathrm{Ca}^{2+}$-release (see review Bers 2002). Thus, cardiac E-C coupling is dependent on extracellular $\mathrm{Ca}^{2+}$ and functional coupling between $\mathrm{Ca}_{\mathrm{v}} 1.2$ 
and RyR2, which is assumed to rely on spatial proximity between the proteins rather than physical interaction. Because of the role of the direct physical interaction between $\mathrm{Ca}_{\mathrm{V}} 1.1$ and RyR1 in skeletal muscle, E-C coupling can proceed for long periods in the absence of extracellular $\mathrm{Ca}^{2+}$ (Armstrong CM 1972; Dulhunty and Gage 1988). The $\mathrm{Ca}_{\mathrm{V}} 1.1$ and RyR1 interaction in skeletal muscle is dependent on the strict geometrical alignments between the two proteins, which has been shown with electron microscopy in different muscle preparations (Takekura et al. 1994; Protasi et al. 1998) A critical determinant of E-C coupling in skeletal muscle is the $\alpha_{1 S}$ II-III loop of $\mathrm{Ca}_{\mathrm{v}} 1.1$, with a minor involvement of the $\alpha_{1 S}$ I-II loop (Tanabe et al. 1990; Nakai et al. 1998; Kugler et al. 2004). Other parts in addition to the $\alpha_{1 S}$ II-III loop are also suggested to be able to interact with RyR, e.g., the carboxyl terminus and the $\alpha_{1 S}$ III-IV loop (Slavik et al. 1997; Leong and MacLennan 1998). The $\beta_{1 \mathrm{a}}$ carboxyl terminus is also important for E-C coupling (Beurg et al. 1999; Sheridan et al. 2003). Multiple regions of RyR 1 are likely to be involved in the interactions with $\mathrm{Ca}_{\mathrm{v}} 1.1$ (Nakai et al. 1998; Proenza et al. 2002; Protasi et al. 2002; Perez et al. 2003; Sheridan et al. 2006). The sites of interaction appear to be distributed over a large part of the cytoplasmic region, among them the divergent region 2 (Sheridan et al. 2006), which has been mapped to the clamp domains (Liu et al. 2004). Freeze-fracture studies suggest subdomains 4 and 6 as the most likely locations for contact with $\mathrm{Ca}_{\mathrm{V}} 1.1$ (Paolini et al. 2004).

Mechanical E-C coupling may also play a role in other tissues that express $\mathrm{Ca}_{\mathrm{v}}$ isoforms and RyR isoforms; for instance there is evidence for both cardiac-like $\mathrm{Ca}^{2+}$-induced $\mathrm{Ca}^{2+}$-release and skeletal-like protein-protein interactions in neurons (Chavis et al. 1996; Mouton et al. 2001).

$\mathrm{Ca}^{2+}, \mathrm{Mg}^{2+}$, and ATP

$\mathrm{Ca}^{2+}, \mathrm{Mg}^{2+}$, and ATP are important small molecule regulators of RyRs. $\mathrm{Mg}^{2+}$ and ATP modulate RyRs in the cytoplasm and $\mathrm{Ca}^{2+}$ regulates RyRs both in the cytoplasm and in the lumen of SR. The cardiac and skeletal isoform of RyR show some difference in the regulation by these ligands, which has been linked to the different characteristics of E-C coupling in the two isoforms (Lamb 2000; Laver et al. 2001). $\mathrm{Ca}^{2+}$ has both direct effects on RyRs and also regulates RyRs via CaM and CaMKII. RyR1 activity shows a bell-shaped dependence on $\mathrm{Ca}^{2+}$ concentration and is activated by low $\mathrm{Ca}^{2+}$ concentration $(\sim 1 \mu \mathrm{M})$ by binding to specific high-affinity $\mathrm{Ca}^{2+}$ sites, and inhibited by high $\mathrm{Ca}^{2+}$ concentration $(\sim 1 \mathrm{mM})$ by binding to less selective low-affinity $\mathrm{Ca}^{2+}$ sites (Meissner et al. 1986; Meissner 1994; Meissner et al. 1997). Luminal $\mathrm{Ca}^{2+}$, i.e., $\mathrm{SR} \mathrm{Ca}^{2+}$ is also suggested to stimulate $\mathrm{Ca}^{2+}$ release in skeletal and cardiac muscle. Single channel measurements with increased store $\mathrm{Ca}^{2+}$ load have shown an increase in the sensitivity of $\mathrm{Ca}^{2+}$ release in the presence of cytosolic agonists such as ATP and caffeine (Smith et al. 1986; Sitsapesan 1995; Györke and Györke 1998; Xu et al. 1998; Laver et al. 2004). However, there have been conflicting results regarding luminal $\mathrm{Ca}^{2+}$ regulation and the source of these discrepancies is unclear. These might reflect altered mechanisms because of different experimental conditions, for example, differences in membrane preparation that results in variation of the protein complexes formed between RyR and calsequestrin, triadin, and junctin that are known to regulate $\mathrm{RyR}$ via luminal $\mathrm{Ca}^{2+}$ (Györke et al. 2004). $\mathrm{Mg}^{2+}$ is believed to inhibit RyRs by two mechanisms: reducing RyR open probability by competing with high-affinity $\mathrm{Ca}^{2+}$ activation sites, or by binding to less selective low-affinity $\mathrm{Ca}^{2+}$ sites that also mediate $\mathrm{Ca}^{2+}$ inhibition (Meissner et al. 1986; Laver et al. 1997). Noteworthy, there is a predicted difference in $\mathrm{Mg}^{2+}$ inhibition among RyR1, RyR2, and RyR3. RyR2 and RyR3 are activated by $\mathrm{Ca}^{2+}$ to greater extent than RyR1 and require higher $\mathrm{Ca}^{2+}$ concentration for inactivation. Hence, at elevated cytoplasmic $\mathrm{Ca}^{2+}$ concentrations $\mathrm{Mg}^{2+}$ causes potent RyR1 inhibition and relatively little inhibition of RyR2 and RyR3 (Lamb 2000; Meissner 2002).

ATP is an activator of RyRs. Various other adenine nucleotides (ADP, AMP, cAMP, adenosine, 


\section{J.T. Lanner et al.}

and adenine) also potentiate $\mathrm{SR} \mathrm{Ca}^{2+}$ release but are less efficacious than ATP (Meissner 1984). In vitro studies have shown that skeletal muscle RyR1 can be activated by ATP in the absence of $\mathrm{Ca}^{2+}$, but $\mathrm{Ca}^{2+}$ needs to be present for maximal activation (Meissner 1984; Meissner et al. 1986; Laver et al. 2001). Cardiac RyR is not activated by ATP in the absence of $\mathrm{Ca}^{2+}$. However, ATP augments the $\mathrm{Ca}^{2+}$ induced activation of RyR2, but the effects are more modest than those seen with RyR1 (Xu et al. 1996; Kermode et al. 1998). In cells, most ATP is in complex with $\mathrm{Mg}^{2+}$. Therefore, it is probable that under physiological conditions the MgATP complex rather than free ATP regulates $\mathrm{Ca}^{2+}$ release. The presence of high concentrations of free $\mathrm{Mg}^{2+}$ in cells and its inhibitory effects on RyR makes it difficult to determine the different effects of ATP and MgATP.

\section{Calmodulin}

CaM is a ubiquitously expressed $17-\mathrm{kDa} \mathrm{Ca}^{2+}-$ binding protein that regulates RyRs by direct binding. CaM is also known to bind to and regulate $\mathrm{Ca}_{\mathrm{v}} 1.1$ and $\mathrm{Ca}_{\mathrm{v}} 1.2$ (Tang et al. 2002; Ohrtman et al. 2008; Halling et al. 2009). CaM contains four EF-hand $\mathrm{Ca}^{2+}$ binding pockets (two in the carboxy-terminal domain and two in the amino-terminal domain of the protein) and binds to one site per RyR subunit (four per tetramer) (Moore et al. 1999a). All three RyR isoforms bind and are regulated by CaM both in its $\mathrm{Ca}^{2+}$-free (apoCaM) and $\mathrm{Ca}^{2+}$-bound (CaCaM) states (Tripathy et al. 1995; Yamaguchi et al. 2005). ApoCaM is a partial agonist whereas $\mathrm{CaCaM}$ is an inhibitor of RyR1 and SR $\mathrm{Ca}^{2+}$ release (Rodney et al. 2000). CaM binding site involves amino acids 3614-3643 of the RyR1 rabbit sequence (Takeshima et al. 1989; Moore et al. 1999b; Yamaguchi et al. 2003; Zhang et al. 2003). Cryo-EM difference mapping of the three-dimensional structures of RyR1 with and without added CaM has suggested that the $\mathrm{CaCaM}$ binding site is located in subdomain 3. The site seems to be displaced to $\sim 33 \AA$ in the presence of $\mathrm{Ca}^{2+}$ with respect to its position for apoCaM (Wagenknecht et al. 1994; Wagenknecht et al. 1997; Samsó and
Wagenknecht 2002). This displacement could be caused by a movement of the CaM upon binding calcium and/or a movement of the CaM binding site when RyR1 binds $\mathrm{Ca}^{2+}$. The structure of CaM bound to a RyR1 peptide (3614-3643) has been visualized by NMR residual dipolar coupling (Maximciuc et al. 2006). Amino acids $3615-3628$ contact the carboxy lobe of CaM, whereas amino acids 36283637 bind the amino lobe of CaM. In cardiac muscle, CaM shifts the $\mathrm{Ca}^{2+}$-dependence of RyR2 activation to higher $\mathrm{Ca}^{2+}$ concentrations and hence decreases the RyR2 opening at all $\mathrm{Ca}^{2+}$ concentrations (Balshaw et al. 2001; Yamaguchi et al. 2003). Recently reduced affinity for CaM binding to RyR2 with PKA phosphorylation was found in a CPVT-associated mouse model (Arg2474Ser), resulting in spontaneous local $\mathrm{Ca}^{2+}$ release events leading to lethal arrythmias (Xu et al. 2010). In addition to CaM, a number of other EF-hand containing proteins have been recognized to interact with and regulate RyR, including calumenin and S100A1 (Jung et al. 2006; Wright et al. 2008). S100A1 has been found to compete with CaM for the RyR binding site (Wright et al. 2008). The questions of which of these EF-hand proteins actually regulate RyRs in vivo have yet to be answered.

\section{Calsequestrin}

Calsequestrin (CSQ) is the major intra-SR $\mathrm{Ca}^{2+}$ buffer. There are two genes encoding CSQ; type 1 CSQ (CSQ1) expressed in skeletal muscle and type 2 CSQ (CSQ2) expressed in cardiac and low levels in slow-twitch skeletal muscle. In addition to functioning as a $\mathrm{Ca}^{2+}$ buffer, CSQ forms oligomers in the lumen and interacts with the RyR anchoring proteins junctin and triadin embedded in the SR membrane. Together these three proteins appear to regulate RyR activity. The molecular details underlying these interactions have not been elucidated in either skeletal or cardiac muscle (Beard et al. 2009; Györke et al. 2009).

CSQ1 and CSQ2 appear to have unique isoform-specific properties in skeletal and cardiac muscle. CSQ1 reduces the activity of 
RyR1 whereas CSQ2 increases the open probability of RyR1 and RyR2 (Wei et al. 2009). CSQ1-mediated inhibition of $\mathrm{Ca}^{2+}$ release during a single action potential may tune RyR1 activation to stimulation frequency and maintain $\mathrm{Ca}^{2+}$ release with repeated stimulation. In cardiac muscle CSQ2 may facilitate high rates of $\mathrm{Ca}^{2+}$ efflux through RyR2 during systole resulting in fast activation of contraction.

Recently, a mutation in the CSQ2 gene was linked to exercise-induced cardiac death caused by CPVT, although under basal conditions the cardiac contractility is apparently normal in subjects lacking functional CSQ2 (Postma et al. 2002). Knollmann and coworkers showed that Casq2-null mice are viable and display normal $\mathrm{SR} \mathrm{Ca}^{2+}$ release and contractile function under basal conditions. However, exposure to catecholamines in Casq2-null myocytes caused increased diastolic SR $\mathrm{Ca}^{2+}$ leak, resulting in premature spontaneous $\mathrm{SR} \mathrm{Ca}^{2+}$ releases that triggered beats indicating that these mice are susceptible to catecholaminergic ventricular arrhythmias (Knollmann et al. 2006).

\section{FK506-Binding Protein 12 and 12.6 (FKBP12 and FKBP12.6)}

FKBPs are named according to their molecular mass and belong to the immunophilins, a family of highly conserved proteins that bind immunosuppressive drugs such as FK506 and rapamycin. FKBPs are expressed in most tissues and are involved in a number of biochemical processes such as protein folding, receptor signaling, protein trafficking, and transcription. FKBP12 and FKBP12.6 (also known as calstabin 1 and 2 , respectively) physically interact with all three isoforms of RyR but have different expression levels and binding affinity in different tissues (Chelu et al. 2004). FKBP12 copurifies with RyR1 (Jayaraman et al. 1992; Brillantes et al. 1994) and FKBP12.6 copurifies with RyR2 (Timerman et al. 1995; Timerman et al. 1996; Barg et al. 1997; Jeyakumar et al. 2001; Masumiya et al. 2003). Although somewhat controversial, a component of the FKBP12 binding site appears to be located between amino acids 2458 and 2468 of RyR1 (Rabbit sequence, SwissProt accession \#P11716). Mutation of the amino acid Val2461 abolishes the FKBP12 binding (Gaburjakova et al. 2001; Avila et al. 2003). The amino-terminal and the carboxy-terminal regions of RyR2 have also been suggested to interact with FKBP12.6 (Masumiya et al. 2003; Xiao et al. 2004; Zissimopoulos and Lai 2005). Difference mapping of threedimensional reconstructions of RyR with and without FKBP12 or 12.6 places the FKBPs binding site between subdomains 3, 5, and 9 (Wagenknecht et al. 1996; Wagenknecht et al. 1997; Samsó et al. 2006; Sharma et al. 2006). In agreement with this localization, FRET studies have localized the FKBP12 (Cornea et al. 2009) and the FKBP12.6 (Cornea et al. 2010) binding site to the same area as the model from Samsó et al 2006. Furthermore, both FKBP12 and 12.6 bind RyR1 and RyR2 in the same orientation (Cornea et al. 2010). Comparison of this location with the docking of the IP3 homology model, which includes the suppressor domain and the IP3-binding core region both with high sequence similarity to RyR1 aminoterminus, suggests a binding pocket for FKBP12 formed by Glu161, Arg164, Arg402, and Ile404 (Serysheva et al. 2008).

In mammals FKBP12 and 12.6 bind to RyRs with a stoichiometry of four FKBPs per RyR homotetramer (Jayaraman et al. 1992; Timerman et al. 1993; Qi et al. 1998). Under physiological conditions (i.e., the absence of immunosuppressive drugs), FKBPs are though to bind to RyRs with high affinity and stabilize the closed state of the channel (Ahern et al. 1994; Brillantes et al. 1994; McCall et al. 1996; Ahern et al. 1997; Marx et al. 1998; Marx et al. 2001). Removal of FKBP12, by preventing rebinding with an immunosuppressive drug or as the result of a genetic FKBP deficiency leads to greater open probability of the channel and longer mean open times (Ahern et al. 1997; Marx et al. 1998; Shou et al. 1998). Furthermore, FKBP12 displacement in skeletal muscle alters the coupling between RyR1 and $\mathrm{Ca}_{\mathrm{V}} 1.1$. The consequences of these changes are dependent on muscle type and activity (Tang et al. 2004). In cardiac muscle, FKBP12 deficiency results in cardiomyopathy and ventricle septal defects 
J.T. Lanner et al.

that mimic human congenital heart disorder (Shou et al. 1998).

\section{PKA and CaMKII Phosphorylation}

The importance of RyR phosphorylation in modulation of $\mathrm{Ca}^{2+}$ release from SR was first established in the heart (Takasago et al. 1989). The functional consequences of phosphorylation on RyR function and the identity of the enzymes involved have been the focus of considerable debate. RyRs have several potential phosphorylation sites in their cytoplasmic domains. PKA, CaMKII, and cGMP-dependent kinase (PKG) have all been shown to phosphorylate RyR isoforms (Rodriguez et al. 2003; Wehrens et al. 2004; Xiao et al. 2006; Huke and Bers 2007).

The "fight or flight" response is a classic physiological stress pathway that involves activation of the sympathetic nervous system (SNS) that among other effects results in larger and faster $\mathrm{Ca}^{2+}$ transients and subsequently stronger and faster muscle contractions (Bers 2002). SNS activation causes $\beta$-adrenergic stimulation of the muscle, which via an intracellular signaling cascade results in activation of PKA. SNS-activated PKA phosphorylates RyR, altering its gating properties, but also phosphorylates several other key proteins involved in $\mathrm{Ca}^{2+}$ handling such as troponin I and phospholamban (Valdivia et al. 1995; Li et al. 2000; Kentish et al. 2001; Reiken et al. 2003). Modified RyR function is associated with increased SR $\mathrm{Ca}^{2+}$ leak in heart, which could contribute to reduced contractile function and increased propensity to arrhythmias. Altered phosphorylation of RyR2 has been suggested as one possible explanation for RyR dysfunction. Marks and colleagues propose that a hyper-adrenergic state that occurs in heart failure or during extreme stress, including exercise, leads to hyperphosphorylation of RyR serine residues (Ser2030, Ser2809 in RyR2 and Ser2843 in RyR1). They also suggest that hyperphosphorylation causes FKBPs to dissociate from RyRs, producing "leaky channels" (i.e., channels prone to open at rest). Such leaky channels could underlie increased risk for arrhythmias in heart failure and contribute to decreased muscle force production by reducing
$\mathrm{SR} \mathrm{Ca}^{2+}$ store content (Marx et al. 2000; Reiken et al. 2003). However, other groups have not found PKA-dependent hyperphosphorylation in failing hearts (Xiao et al. 2005). In addition, other laboratories suggest that CamKII-dependent phosphorylation of RyR2 is involved in enhanced SR $\mathrm{Ca}^{2+}$ leak and reduced SR $\mathrm{Ca}^{2+}$ load in heart failure and may contribute to arrhythmias and contractile dysfunction (Ai et al. 2005; Chelu et al. 2009; Curran et al. 2010; Neef et al. 2010). Phosphorylation of other targets of these kinases (troponin I, sarcolemmal $\mathrm{Ca}^{2+}$ channels, and phospholamban) could also alter the $\mathrm{Ca}^{2+}$ handling in cardiac and skeletal muscle.

CaMKII is modulated by changes in intracellular $\mathrm{Ca}^{2+}\left(\left[\mathrm{Ca}^{2+}\right]_{\mathrm{i}}\right)$, although little is still known quantitatively about the role of dynamic $\left[\mathrm{Ca}^{2+}\right]_{\mathrm{i}}$ fluctuations in the activation of CaMKII (Huke and Bers 2007; Aydin et al. 2007). CaMKII phosphorylates the same residues on RyR1 as PKA and also phosphorylates several other proteins such as troponin I, sarcolemmal $\mathrm{Ca}^{2+}$ channels, and phospholamban. Ser2808 on RyR2 was first described as a CaMKII phosphorylation site, but it was later shown that both PKA and PKG also phosphorylate this site (Witcher et al. 1991; Rodriguez et al. 2003; Wehrens et al. 2004; Xiao et al. 2006; Huke and Bers 2007). Ser2814, however, appears to only be phosphorylated by CaMKII whereas Ser2030 is only phosphorylated by PKA (Wehrens et al. 2004; Xiao et al. 2006).

\section{Reactive Oxygen Species and Reactive Nitrogen Species}

Sulfhydryl groups ( $\mathrm{SH}$, also called thiol) of cysteine (Cys) residues are potential targets for reduction/oxidation (redox) modifications of proteins. Alteration in the redox state of $\mathrm{SH}$ groups of two neighboring cysteine residues can lead to formation or breaking of disulfide bonds, which can modify both the structure and function of proteins. Low concentrations of redox active molecules (reactive oxygen species/reactive nitrogen species; ROS/RNS) constitute a basal endogenous redox buffering system that reversibly interacts with proteins. 
Both RyR1 and RyR2 have nitric oxide (NO) covalently bound to cysteines (i.e., S-nitrosylation) and this posttranslational modification is reversible (Xu et al. 1998; Eu et al. 2000; Sun et al. 2008). High levels of ROS/RNS are able to irreversibly modify and even damage proteins in cardiac ischemia-reperfusion injury (Ferdinandy and Schulz 2003).

RyR is an established redox-sensitive channel and alterations in its redox state can result in either activation (Stoyanovsky et al. 1997; Eager and Dulhunty 1998) or inactivation (Boraso and Williams 1994; Marengo et al. 1998). Other key components of $\mathrm{Ca}^{2+}$ regulation and E-C coupling, e.g., SERCA and $\mathrm{Ca}_{\mathrm{v}}$ 's, are also redox modulated. RyR has $\sim 100$ cysteines per subunit and $\sim 20$ of them have been estimated to be free for redox modifications by oxidation, nitrosylation, or alkylation by the redox active molecule glutathione (Zable et al. 1997; Xu et al. 1998). A number of redox-sensitive cysteines have been identified in both the open and closed state of the channel and appear to be distributed across the primary structure of cytoplasmic region (Voss et al. 2004; Aracena et al. 2006). Several of these sites have been mapped to the clamp domains like Cys36 and Cys315 (Liu et al. 2005; Amador 2009; Hamilton and Serysheva 2009; Lobo and Van Petegem 2009), whereas the Cys3635 is located in the subdomain 3 in the CaM binding site (Moore et al. 1999b; Sun et al. 2001). S-nitrosylation of Cys3635 has been shown to reverse the CaM inhibition on RyR1 and to activate the channel (Moore et al. 1999b). The S-nitrosylation of Cys3635 appears to occur only at physiological tissue $\mathrm{O}_{2}$ tension $\left(\mathrm{pO}_{2} ; \sim 10 \mathrm{~mm} \mathrm{Hg}\right.$ ) and facilitates muscle contraction ( $\mathrm{Eu}$ et al. 2003). Moreover, increased S-nitrosylationinduced RyR1 activity is suggested to sensitize RyR1 to environmental heat stress and $\mathrm{MH}$ crises (Durham et al. 2008). Increased RyR1 nitrosylation has also been observed in muscle dystrophy and is thought to contribute to muscle weakness by increased SR $\mathrm{Ca}^{2+}$ leak (Bellinger et al. 2009). In comparison to RyR1, no specific redox sensitive cysteine residues have yet been identified for RyR2. RyR2 is also $\mathrm{pO}_{2}$-responsive but is not activated or
S-nitrosylated directly by NO; instead activation and $S$-nitrosylation of RyR2 requires $S$-nitrosoglutathione (Sun et al. 2008).

\section{CONCLUDING REMARKS}

Primary sequence and location of several mutations are identified for RyR, but unanswered questions and debated topics still remain regarding the tertiary structure, the macromolecular interactions, and the regulation of RyR. The large size of RyR makes it more challenging to study, but new insights into the detailed structure of RyR are emerging with the continuous improvement and refinement of technologies such as cryo-EM and FRET-based assays. Resolution of the structure of RyR is progressing steadily, and ultimately we will have a map including carbon backbones, side-chains, menbrane spanning regions and binding sites of interacting molecules. Along with our understanding of RyRs structure, it is likely that the number of known modulators that interact with RyR will also increase. Although the basic role and function of RyR in E-C coupling in skeletal and cardiac muscle is well established, further refinement of our understanding of the many modulators of RyR will be important in the development of therapeutics for treatment of cardiac and skeletal muscle diseases.

\section{ACKNOWLEDGMENT}

Special thanks to Irina Serysheva for providing the Cryo-EM figure. JT Lanner is supported by a fellowship from the Swedish Research Council.

\section{REFERENCES}

Ahern GP, Junankara PR, Dulhunty AF. 1994. Single channel activity of the ryanodine receptor calcium release channel is modulated by FK-506. FEBS Lett 352: 369-374.

Ahern GP, Junankar PR, Dulhunty AF. 1997. Subconductance states in single-channel activity of skeletal muscle ryanodine receptors after removal of FKBP12. Biophys J 72: $146-162$.

Ai X, Curran JW, Shannon TR, Bers DM, Pogwizd SM. 2005. $\mathrm{Ca}^{2+} /$ Calmodulin-Dependent Protein Kinase Modulates Cardiac Ryanodine Receptor Phosphorylation and Sarcoplasmic Reticulum $\mathrm{Ca}^{2+}$ Leak in Heart Failure. Circ Res 97: 1314-1322. 
J.T. Lanner et al.

Amador FJ, Liu S, Ishiyama N, Plevin MJ, Wilson A, Maclennan DH, Ikura M. 2009. Crystal structure of type I ryanodine receptor amino-terminal -trefoil domain reveals a disease-associated mutation "hot spot" loop. Proc Natl Acad Sci 106: 11040-11044.

Aracena P, Aguirre P, Munoz P, Nunez MT. 2006. Iron and glutathione at the crossroad of redox metabolism in neurons. Biol Res 39: 157-165.

Armstrong CM, BF, Horowicz P. 1972. Twitches in the presence of ethylene glycol bis(-aminoethyl ether)-N,N'tetracetic acid. Biochim Biophys Acta 267: 605-608.

Avila G, Lee EH, Perez CF, Allen PD, Dirksen RT. 2003. FKBP12 Binding to RyR1 Modulates ExcitationContraction Coupling in Mouse Skeletal Myotubes. J Biol Chem 278: 22600-22608.

Aydin J, Korhonen T, Tavi P, Allen DG, Westerblad H, Bruton JD. 2007. Activation of $\mathrm{Ca}^{2+}$-dependent protein kinase II during repeated contractions in single muscle fibres from mouse is dependent on the frequency of sarcoplasmic reticulum $\mathrm{Ca}^{2+}$ release. Acta Physiolog 191: 131-137.

Balshaw D, Gao L, Meissner G. 1999. Luminal loop of the ryanodine receptor: A pore-forming segment? Proc Natl Acad Sci 96: 3345-3347.

Balshaw DM, Xu L, Yamaguchi N, Pasek DA, Meissner G. 2001. Calmodulin Binding and Inhibition of Cardiac Muscle Calcium Release Channel (Ryanodine Receptor). J Biol Chem 276: 20144-20153.

Barg S, Copello JA, Fleischer S. 1997. Different interactions of cardiac and skeletal muscle ryanodine receptors with FK-506 binding protein isoforms. Am J Physiol Cell Physiol 272: C1726-C1733.

Beard N, Wei L, Dulhunty A. 2009. $\mathrm{Ca}^{2+}$ signaling in striated muscle: the elusive roles of triadin, junctin, and calsequestrin. Eur Biophys J 39: 27-36.

Bellinger AM, Reiken S, Carlson C, Mongillo M, Liu X, Rothman L, Matecki S, Lacampagne A, Marks AR. 2009. Hypernitrosylated ryanodine receptor calcium release channels are leaky in dystrophic muscle. Nat Med 15: 325-330.

Benacquista BL, Sharma MR, Samsó M, Zorzato F, Treves S, Wagenknecht T. 2000. Amino Acid Residues 44254621 Localized on the Three-Dimensional Structure of the Skeletal Muscle Ryanodine Receptor. Biophys J 78: 1349-1358.

Bers DM. 2002. Cardiac excitation-contraction coupling. Nature 415: 198-205.

Bers DM, Stiffel VM. 1993. Ratio of ryanodine to dihydropyridine receptors in cardiac and skeletal muscle and implications for E-C coupling. Am J Physiol Cell Physiol 264: C1587-C1593.

Beurg M, Ahern CA, Vallejo P, Conklin MW, Powers PA, Gregg RG, Coronado R. 1999. Involvement of the Carboxy-Terminus Region of the Dihydropyridine Receptor $\beta 1$ la Subunit in Excitation-Contraction Coupling of Skeletal Muscle. Biophys J 77: 2953-2967.

Boraso A, Williams AJ. 1994. Modification of the gating of the cardiac sarcoplasmic reticulum $\mathrm{Ca}^{2+}$-release channel by $\mathrm{H} 2 \mathrm{O} 2$ and dithiothreitol. Am J Physiol Heart Circ Physiol 267: H1010-H1016.

Brillantes AB, Ondrias K, Scott A, Kobrinsky E, Ondriasova E, Moschella MC, Jayaraman T, Landers M, Ehrlich BE,
Marks AR. 1994. Stabilization of calcium release channel (ryanodine receptor) function by FK506-binding protein. Cell 77: 513-523.

Britt LD, Dascombe WH, Rodriguez A. 1991. New horizons in management of hypothermia and frostbite injury. Surg Clin North Am 71: 345-370.

Capacchione JF, Sambuughin N, Bina S, Mulligan LP, Lawson TD, Muldoon SM. 2010. Exertional rhabdomyolysis and malignant hyperthermia in a patient with ryanodine receptor type 1 gene, L-type calcium channel alpha-1 subunit gene, and calsequestrin-1 gene polymorphisms. Anesthesiology 112: 239-244.

Chavis P, Fagni L, Lansman JB, Bockaert J. 1996. Functional coupling between ryanodine receptors and L-type calcium channels in neurons. Nature 382: 719-722.

Chelu MG, Danila CI, Gilman CP, Hamilton SL. 2004. Regulation of Ryanodine Receptors by FK506 Binding Proteins. Trends Cardiovasc Med 14: 227-234.

Chelu MG, Sarma S, Sood S, Wang S, van Oort RJ, Skapura DG, Li N, Santonastasi M, Muller FU, Schmitz W, et al 2009. Calmodulin kinase II-mediated sarcoplasmic reticulum $\mathrm{Ca}^{2+}$ leak promotes atrial fibrillation in mice. J Clin Invest 119: 1940-1951.

Chen SR, MacLennan DH. 1994. Identification of calmodulin-, $\mathrm{Ca}^{2+}-$, and ruthenium red-binding domains in the $\mathrm{Ca}^{2+}$ release channel (ryanodine receptor) of rabbit skeletal muscle sarcoplasmic reticulum. J Biol Chem 269: 22698-22704.

Chu A, Diaz-Muñoz M, Hawkes MJ, Brush K, Hamilton SL. 1990. Ryanodine as a probe for the functional state of the skeletal muscle sarcoplasmic reticulum calcium release channel. Mol Pharmacol 37: 735-741.

Cornea RL, Nitu F, Gruber S, Kohler K, Satzer M, Thomas DD, Fruen BR. 2009. FRET-based mapping of calmodulin bound to the RyR1 $\mathrm{Ca}^{2+}$ release channel. Proc Natl Acad Sci 106: 6128-6133.

Cornea RL, Nitu FR, Samsó M, Thomas DD, Fruen BR. 2010. Mapping the ryanodine receptor (RyR) FK506-binding protein (FKBP) subunit using fluorescence resonance energy transfer (FRET). J Biol Chem 285: 19219-19226.

Corrado D, Basso C, Thiene G. 2000. Arrhythmogenic right ventricular cardiomyopathy: diagnosis, prognosis, and treatment. Heart 83: 588-595.

Curran J, Brown KH, Santiago DJ, Pogwizd S, Bers DM, Shannon TR. 2010. Spontaneous Ca waves in ventricular myocytes from failing hearts depend on $\mathrm{Ca}^{2+}$ calmodulin-dependent protein kinase II. J Mol Cell Cardiol 49: 25-32.

Dalla Volta S, Battaglia G, Zerbini E. 1961. "Auricularization" of right ventricular pressure curve. Am Heart J 61: $25-33$.

Denborough MA, Forster JFA, Lovell RRH, Maplestone PA, Villiers JD. 1962. Anaesthetic Deaths in a Family. Br J Anaesth 34: 395-396.

Dirksen RT, Avila G. 2002. Altered ryanodine receptor function in central core disease: leaky or uncoupled $\mathrm{Ca}^{2+}$ release channels? Trends Cardiovasc Med 12: 189-197.

Du GG, Khanna VK, MacLennan DH. 2000. Mutation of divergent region 1 alters caffeine and $\mathrm{Ca}^{2+}$ sensitivity of 
the skeletal muscle $\mathrm{Ca}^{2+}$ release channel (ryanodine receptor). J Biol Chem 275: 11778-11783.

Du GG, Guo X, Khanna VK, MacLennan DH. 2001. Functional Characterization of Mutants in the Predicted Pore Region of the Rabbit Cardiac Muscle $\mathrm{Ca}^{2+}$ Release Channel (Ryanodine Receptor Isoform 2). J Biol Chem 276: $31760-31771$.

Du GG, Sandhu B, Khanna VK, Guo XH, MacLennan DH. 2002. Topology of the $\mathrm{Ca}^{2+}$ release channel of skeletal muscle sarcoplasmic reticulum (RyR1). Proc Natl Acad Sci 99: $16725-16730$.

Dulhunty AF, Gage PW. 1988. Effects of extracellular calcium concentration and dihydropyridines on contraction in mammalian skeletal muscle. J Physiol 399: 63-80.

Durham WJ, Aracena-Parks P, Long C, Rossi AE, Goonasekera SA, Boncompagni S, Galvan DL, Gilman CP, Baker MR, Shirokova N, et al. 2008. RyR1 S-Nitrosylation Underlies Environmental Heat Stroke and Sudden Death in Y522S RyR1 Knockin Mice. Cell 133: 53-65.

Eager KR, Dulhunty AF. 1998. Activation of the Cardiac Ryanodine Receptor by Sulfhydryl Oxidation is Modified by $\mathrm{Mg}^{2+}$ and ATP. J Memb Biol 163: 9-18.

Ellis FR, Halsall PJ, Harriman DG. 1988. Malignant hyperpyrexia and sudden infant death syndrome. Br J Anaesth 60: $28-30$.

Endo M. 1977. Calcium release from the sarcoplasmatic reticulum. Physiol Rev 57: 71-108.

Eu JP, Hare JM, Hess DT, Skaf M, Sun J, Cardenas-Navina I, Sun QA, Dewhirst M, Meissner G, Stamler JS. 2003. Concerted regulation of skeletal muscle contractility by oxygen tension and endogenous nitric oxide. Proc Nat Acad Sci 100: 15229-15234.

Eu JP, Sun J, Xu L, Stamler JS, Meissner G. 2000. The Skeletal Muscle Calcium Release Channel: Coupled O2 Sensor and NO Signaling Functions. Cell 102: 499-509.

Ferdinandy P, Schulz R. 2003. Nitric oxide, superoxide, and peroxynitrite in myocardial ischaemia-reperfusion injury and preconditioning. Br J Pharmacol 138: 532-543.

Ferreiro A, Monnier N, Romero NB, Leroy JP, Bonnemann C, Haenggeli CA, Straub V, Voss WD, Nivoche Y, Jungbluth $\mathrm{H}$, et al. 2002. A recessive form of central core disease, transiently presenting as multi-minicore disease, is associated with a homozygous mutation in the ryanodine receptor type 1 gene. Ann Neurol 51: 750-759.

Fill M, Copello JA. 2002. Ryanodine receptor calcium release channels. Physiol Rev 82: 893-922.

Fontaine G, Frank R, Guiraudon G, Pavie A, Tereau Y, Chomette G, Grosgogeat Y. 1984. Significance of intraventricular conduction disorders observed in arrhythmogenic right ventricular dysplasia. Arch Mal Coeur Vaiss 77: 872-879.

Fontaine G, Gallais Y, Fornes P, Hebert JL, Frank R. 2001. Arrhythmogenic right ventricular dysplasia/cardiomyopathy. Anesthesiology 95: 250-254.

Franzini-Armstrong C, Nunzi G. 1983. Junctional feet and particles in the triads of a fast-twitch muscle fibre. $J$ Muscle Res Cell Mot 4: 233-252.

Furuichi T, Furutama D, Hakamata Y, Nakai J, Takeshima H, Mikoshiba K. 1994. Multiple types of ryanodine receptor $/ \mathrm{Ca}^{2+}$ release channels are differentially expressed in rabbit brain. J Neurosci 14: 4794-4805.
Gaburjakova M, Gaburjakova J, Reiken S, Huang F, Marx SO, Rosemblit N, Marks AR. 2001. FKBP12 Binding Modulates Ryanodine Receptor Channel Gating. J Biol Chem 276: 16931-16935.

Gao L, Balshaw D, Xu L, Tripathy A, Xin C, Meissner G. 2000. Evidence for a Role of the Lumenal M3-M4 Loop in Skeletal Muscle $\mathrm{Ca}^{2+}$ Release Channel (Ryanodine Receptor) Activity and Conductance. Biophys J 79: $828-840$.

Garcia J, Tanabe T, Beam KG. 1994. Relationship of calcium transients to calcium currents and charge movements in myotubes expressing skeletal and cardiac dihydropyridine receptors. J Cell Biol 103: 125-147.

George CH, Higgs GV, Lai FA. 2003. Ryanodine receptor mutations associated with stress-induced ventricular tachycardia mediate increased calcium release in stimulated cardiomyocytes. Circ Res 93: 531-540.

Giannini G, Clementi E, Ceci R, Marziali G, Sorrentino V. 1992. Expression of a ryanodine receptor- $\mathrm{Ca}^{2+}$ channel that is regulated by TGF-beta. Science 257: 91-94.

Giannini G, Conti A, Mammarella S, Scrobogna M, Sorrentino V. 1995. The ryanodine receptor/calcium channel genes are widely and differentially expressed in murine brain and peripheral tissues. J Cell Biol 128: 893-904.

Györke I, Györke S. 1998. Regulation of the Cardiac Ryanodine Receptor Channel by Luminal $\mathrm{Ca}^{2+}$ Involves Luminal $\mathrm{Ca}^{2+}$ Sensing Sites. Biophys J 75: 2801-2810.

Györke S, Stevens SCW, Terentyev D. 2009. Cardiac calsequestrin: quest inside the SR. J Physiol 587: 3091-3094.

Györke I, Hester N, Jones LR, Györke S. 2004. The Role of Calsequestrin, Triadin, and Junctin in Conferring Cardiac Ryanodine Receptor Responsiveness to Luminal Calcium. Biophys J 86: 2121-2128.

Hakamata Y, Nakai J, Takeshima H, Imoto K. 1992. Primary structure and distribution of a novel ryanodine receptor/ calcium release channel from rabbit brain. FEBS Lett 312: 229-235.

Halling DB, Georgiou DK, Black DJ, Yang G, Fallon JL, Quiocho FA, Pedersen SE, Hamilton SL. 2009. Determinants in $\mathrm{Ca}_{\mathrm{V}} 1$ Channels That Regulate the $\mathrm{Ca}^{2+}$ Sensitivity of Bound Calmodulin. J Biol Chem 284: 20041-20051.

Hamada T, Sakube Y, Ahnn J, Kim DH, Kagawa H. 2002. Molecular dissection, tissue localization and $\mathrm{Ca}^{2+}$ binding of the ryanodine receptor of Caenorhabditis elegans. J Mol Biol 324: 123-135.

Hamilton SL, Serysheva II. 2009. Ryanodine Receptor Structure: Progress and Challenges. J Biol Chem 284: 4047-4051.

Hayek SM, Zhao J, Bhat M, Xu X, Nagaraj R, Pan Z, Takeshima H, Ma J. 1999. A negatively charged region of the skeletal muscle ryanodine receptor is involved in $\mathrm{Ca}^{2+}$. dependent regulation of the $\mathrm{Ca}^{2+}$ release channel. FEBS Lett 461: 157-164.

Huke S, Bers DM. 2007. Temporal dissociation of frequencydependent acceleration of relaxation and protein phosphorylation by CaMKII. J Mol Cell Cardiol 42: 590-599.

Ikemoto N, Antoniu B, Kang JJ, Meszaros LG, Ronjat M. 1991. Intravesicular calcium transient during calcium release from sarcoplasmic reticulum. Biochemistry 30: 5230-5237. 
J.T. Lanner et al.

Imagawa T, Smith JS, Coronado R, Campbell KP. 1987. Purified ryanodine receptor from skeletal muscle sarcoplasmic reticulum is the $\mathrm{Ca}^{2+}$-permeable pore of the calcium release channel. J Biol Chem 262: 16636-16643.

Inui M, Saito A, Fleischer S. 1987. Purification of the ryanodine receptor and identity with feet structures of junctional terminal cisternae of sarcoplasmic reticulum from fast skeletal muscle. J Biol Chem 262: 1740-1747.

Jayaraman T, Brillantes AM, Timerman AP, Fleischer S, Erdjument-Bromage H, Tempst P, Marks AR. 1992. FK506 binding protein associated with the calcium release channel (ryanodine receptor). J Biol Chem 267: 9474-9477.

Jeyakumar LH, Ballester L, Cheng DS, McIntyre JO, Chang P, Olivey HE, Rollins-Smith L, Barnett JV, Murray K, Xin $\mathrm{H}-\mathrm{B}$, et al. 2001. FKBP Binding Characteristics of Cardiac Microsomes from Diverse Vertebrates. Biochem Biophys Res Comm 281: 979-986.

Jiang D, Xiao B, Zhang L, Chen SR. 2002. Enhanced basal activity of a cardiac $\mathrm{Ca}^{2+}$ release channel (ryanodine receptor) mutant associated with ventricular tachycardia and sudden death. Circ Res 91: 218-225.

Jung DH, Mo SH, Kim DH. 2006. Calumenin, a multiple EF-hands $\mathrm{Ca}^{2+}$-binding protein, interacts with ryanodine receptor-1 in rabbit skeletal sarcoplasmic reticulum. Biochem Biophys Res Comm 343: 34-42.

Jungbluth H. 2007a. Central core disease. Orphanet J Rare Dis 2: 25.

Jungbluth H. 2007b. Multi-minicore Disease. Orphanet J Rare Dis 2: 31 .

Jurkat-Rott K. McCarthy T. Lehmann-Horn F. 2000. Genetics and pathogenesis of malignant hyperthermia. Muscle Nerve 23: 4-17.

Kentish JC, McCloskey DT, Layland J, Palmer S, Leiden JM, Martin AF, Solaro RJ. 2001. Phosphorylation of Troponin I by Protein Kinase A Accelerates Relaxation and Crossbridge Cycle Kinetics in Mouse Ventricular Muscle. Circ Res 88: 1059-1065.

Kermode H, Williams AJ, Sitsapesan R. 1998. The Interactions of ATP, ADP, and Inorganic Phosphate with the Sheep Cardiac Ryanodine Receptor. Biophys J 74: 1296-1304.

Knollmann BRC, Chopra N, Hlaing T, Akin B, Yang T, Ettensohn K, Knollmann BEC, Horton KD, Weissman NJ Holinstat I, et al. 2006. Casq2 deletion causes sarcoplasmic reticulum volume increase, premature $\mathrm{Ca}^{2+}$ release, and catecholaminergic polymorphic ventricular tachycardia. J Clin Invest 116: 2510-2520.

Kugler G, Weiss RG, Flucher BE, Grabner M. 2004. Structural Requirements of the Dihydropyridine Receptor $\alpha 1 S$ II-III Loop for Skeletal-type Excitation-Contraction Coupling. J Biol Chem 279: 4721-4728.

Kuwajima G, Futatsugi A, Niinobe M, Nakanishi S, Mikoshiba K. 1992. Two types of ryanodine receptors in mouse brain: skeletal muscle type exclusively in Purkinje cells and cardiac muscle type in various neurons. Neuron 9: $1133-1142$.

Lahat H, Pras E, Olender T, Avidan N, Ben-Asher E, Man O, Levy-Nissenbaum E, Khoury A, Lorber A, Goldman B, et al. 2001. A missense mutation in a highly conserved region of CASQ2 is associated with autosomal recessive catecholamine-induced polymorphic ventricular tachycardia in Bedouin families from Israel. Am J Hum Genet 69: 1378-1384.

Lai FA, Dent M, Wickenden C, Xu L, Kumari G, Misra M, Lee HB, Sar M, Meissner G. 1992. Expression of a cardiac $\mathrm{Ca}^{2+}$-release channel isoform in mammalian brain. Biochem J 288: 553-564.

Lai FA, Erickson HP, Rousseau E, Liu QY, Meissner G. 1988. Purification and reconstitution of the calcium release channel from skeletal muscle. Nature 331: 315-319.

Lai FA, Misra M, Xu L, Smith HA, Meissner G. 1989. The ryanodine receptor $\mathrm{Ca}^{2+}$-release channel complex of skeletal muscle sarcoplasmic reticulum. Evidence for a cooperatively coupled, negatively charged homotetramer. J Biol Chem 264: 16776-16785.

Laitinen PJ, Swan H, Kontula K. 2003. Molecular genetics of exercise-induced polymorphic ventricular tachycardia: identification of three novel cardiac ryanodine receptor mutations and two common calsequestrin 2 amino-acid polymorphisms. Eur J Hum Genet 11: 888-891.

Lamb G. 2000. Excitation \& Contraction Coupling In Skeletal Muscle: Comparisons with Cardiac Muscle. Clin Exp Pharmacol Physiol 27: 216-224.

Laver DR, Baynes TM, Dulhunty AF. 1997. Magnesium Inhibition of Ryanodine-Receptor Calcium Channels: Evidence for Two Independent Mechanisms. J Memb Biol 156: 213-229.

Laver D, Lenz G, Lamb G. 2001. Regulation of the calcium release channel from rabbit skeletal muscle by the nucleotides ATP, AMP, IMP and adenosine. J Physiol 537: 763-778.

Laver D, O’Neill E, Lamb G. 2004. Luminal $\mathrm{Ca}^{2+}$-regulated $\mathrm{Mg}^{2+}$ inhibition of skeletal RyRs reconstituted as isolated channels or coupled clusters. J Physiol 124: 741-758.

Leong P, MacLennan DH. 1998. The Cytoplasmic Loops between Domains II and III and Domains III and IV in the Skeletal Muscle Dihydropyridine Receptor Bind to a Contiguous Site in the Skeletal Muscle Ryanodine Receptor. J Biol Chem 273: 29958-29964.

Li L, Desantiago J, Chu G, Kranias EG, Bers DM. 2000. Phosphorylation of phospholamban and troponin I in beta -adrenergic-induced acceleration of cardiac relaxation. Am J Physiol Heart Circ Physiol 278: H769-H779.

Liu Z, Wang R, Zhang J, Chen SRW, Wagenknecht T. 2005. Localization of a Disease-associated Mutation Site in the Three-dimensional Structure of the Cardiac Muscle Ryanodine Receptor. J Biol Chem 280: 37941-37947.

Liu Z, Zhang J, Li P, Chen SRW, Wagenknecht T. 2002. Three-dimensional Reconstruction of the Recombinant Type 2 Ryanodine Receptor and Localization of Its Divergent Region 1. J Biol Chem 277: 46712-46719.

Liu Z, Zhang J, Sharma MR, Li P, Chen SRW, Wagenknecht T. 2001. Three-dimensional reconstruction of the recombinant type 3 ryanodine receptor and localization of its amino terminus. Proc Natl Acad Sci 98: 6104-6109.

Liu Z, Zhang J, Wang R, Wayne Chen SR, Wagenknecht T. 2004. Location of Divergent Region 2 on the Threedimensional Structure of Cardiac Muscle Ryanodine Receptor/Calcium Release Channel. J Mol Biol 338: 533-545.

Lobo PA, Van Petegem F. 2009. Crystal Structures of the NTerminal Domains of Cardiac and Skeletal Muscle 
Ryanodine Receptors: Insights into Disease Mutations. Structure 17: 1505-1514.

Ludtke SJ, Serysheva II, Hamilton SL, Chiu W. 2005. The Pore Structure of the Closed RyR1 Channel. Structure 13: $1203-1211$.

Lueck JD, Dirksen RT. 2004. Ryanodinopathies: muscle disorders linked to mutations in ryanodine receptors. Basic Appl Myol 14: 339-352.

Lynch PJ, Tong J, Lehane M, Mallet A, Giblin L, Heffron JJ, Vaughan P, Zafra G, MacLennan DH, McCarthy TV. 1999. A mutation in the transmembrane/luminal domain of the ryanodine receptor is associated with abnormal $\mathrm{Ca}^{2+}$ release channel function and severe central core disease. Proc Natl Acad Sci 96: 4164-4169.

Ma J, Bhat MB, Zhao J. 1995. Rectification of skeletal muscle ryanodine receptor mediated by FK506 binding protein. Biophys J 69: 2398-2404.

MacLennan DH. 1992. The genetic basis of malignant hyperthermia. Trends Pharmacol Sci 13: 330-334.

MacLennan DH, Duff C, Zorzato F, Fujii J, Phillips M, Korneluk RG, Frodis W, Britt BA, Worton RG. 1990. Ryanodine receptor gene is a candidate for predisposition to malignant hyperthermia. Nature 343: 559-561.

Magee KR, Shy GM. 1956. A new congenital nonprogressive myopathy. Brain 79: 610-621.

Marcus FI, Fontaine GH, Guiraudon G, Frank R, Laurenceau JL, Malergue C, Grosgogeat Y. 1982. Right ventricular dysplasia: a report of 24 adult cases. Circulation 65: 384-398.

Marengo JJ, Hidalgo C, Bull R. 1998. Sulfhydryl oxidation modifies the calcium dependence of ryanodine-sensitive calcium channels of excitable cells. Biophy $J$ 74: 1263-1277.

Marks AR, Priori S, Memmi M, Kontula K, Laitinen PJ. 2002. Involvement of the cardiac ryanodine receptor/ calcium release channel in catecholaminergic polymorphic ventricular tachycardia. J Cell Physiol 190: 1-6.

Marks AR, Tempst P, Hwang KS, Taubman MB, Inui M, Chadwick C, Fleischer S, Nadal-Ginard B. 1989. Molecular cloning and characterization of the ryanodine receptor/junctional channel complex cDNA from skeletal muscle sarcoplasmic reticulum. Proc Natl Acad Sci 86: 8683-8687.

Marx SO, Ondrias K, Marks AR. 1998. Coupled Gating Between Individual Skeletal Muscle $\mathrm{Ca}^{2+}$ Release Channels (Ryanodine Receptors). Science 281: 818-821.

Marx SO, Reiken S, Hisamatsu Y, Gaburjakova M, Gaburjakova J, Yang YM, Rosemblit N, Marks AR. 2001. Phosphorylation-dependent regulation of ryanodine receptors: a novel role for leucine/isoleucine zippers. $J$ Cell Biol 153: 699-708.

Marx SO, Reiken S, Hisamatsu Y, Jayaraman T, Burkhoff D, Rosemblit N, Marks AR. 2000. PKA Phosphorylation Dissociates FKBP12.6 from the Calcium Release Channel (Ryanodine Receptor): Defective Regulation in Failing Hearts. Cell 101: 365-376.

Maryon EB, Coronado R, Anderson P. 1996. Unc-68 encodes a ryanodine receptor involved in regulating C. elegans body-wall muscle contraction. J Cell Biol 134: 885-893.
Masumiya H, Wang R, Zhang J, Xiao B, Chen SRW. 2003. Localization of the 12.6-kDa FK506-binding Protein (FKBP12.6) Binding Site to the NH2-terminal Domain of the Cardiac $\mathrm{Ca}^{2+}$ Release Channel (Ryanodine Receptor). J Biol Chem 278: 3786-3792.

Mattei MG, Giannini G, Moscatelli F, Sorrentino V. 1994. Chromosomal localization of murine ryanodine receptor genes RYR1, RYR2, and RYR3 by in situ hybridization. Genomics 22: 202-204.

Maximciuc AA, Putkey JA, Shamoo Y, MacKenzie KR. 2006. Complex of Calmodulin with a Ryanodine Receptor Target Reveals a Novel, Flexible Binding Mode. Structure 14: 1547-1556.

Mayrleitner M, Chandler R, Schindler H, Fleischer S. 1995. Phosphorylation with protein kinases modulates calcium loading of terminal cisternae of sarcoplasmic reticulum from skeletal muscle. Cell Calcium 18: 197-206.

McCall E, Li L, Satoh H, Shannon TR, Blatter LA, Bers DM. 1996. Effects of FK-506 on Contraction and $\mathrm{Ca}^{2+}$ Transients in Rat Cardiac Myocytes. Circ Res 79: 1110-1121.

McGrew SG, Wolleben C, Siegl P, Inui M, Fleischer S. 1989. Positive cooperativity of ryanodine binding to the calcium release channel of sarcoplasmic reticulum from heart and skeletal muscle. Biochemistry 28: 1686-1691.

Meissner G. 1984. Adenine nucleotide stimulation of $\mathrm{Ca}^{2+}$. induced $\mathrm{Ca}^{2+}$-release in sarcoplasmic reticulum. J Biol Chem 259: 2365-2374.

Meissner G. 1994. Ryanodine Receptor/Ca ${ }^{2+}$ Release Channels and Their Regulation by Endogenous Effectors. Ann Rev Physiol 56: 485-508.

Meissner G. 2002. Regulation of mammalian ryanodine receptors. Frontiers in Biosci 7: d2072-2080.

Meissner G, Darling E, Eveleth J. 1986. Kinetics of rapid calcium release by sarcoplasmic reticulum. Effects of calcium, magnesium, and adenine nucleotides. Biochemistry 25: 236-244.

Meissner G, Rios E, Tripathy A, Pasek DA. 1997. Regulation of Skeletal Muscle $\mathrm{Ca}^{2+}$ Release Channel (Ryanodine Receptor) by $\mathrm{Ca}^{2+}$ and Monovalent Cations and Anions. J Biol Chem 272: 1628-1638.

Meng X, Wang G, Viero C, Wang Q, Mi W, Su X-D, Wagenknecht T, Williams AJ, Liu Z, Yin C-C. 2009. CLIC2-RyR1 Interaction and Structural Characterization by Cryoelectron Microscopy. J Mol Biol 387: 320-334.

Mickelson JR, Louis CF. 1996. Malignant hyperthermia: excitation-contraction coupling, $\mathrm{Ca}^{2+}$ release channel, and cell $\mathrm{Ca}^{2+}$ regulation defects. Physiol Rev 76: 537-592.

Monnier N, Romero NB, Lerale J, Nivoche Y, Qi D, MacLennan DH, Fardeau M, Lunardi J. 2000. An autosomal dominant congenital myopathy with cores and rods is associated with a neomutation in the RYR1 gene encoding the skeletal muscle ryanodine receptor. Hum Mol Genet 9: 2599-2608.

Moore CP, Zhang J-Z, Hamilton SL. 1999b. A Role for Cysteine 3635 of RYR1 in Redox Modulation and Calmodulin Binding. J Biol Chem 274: 36831-36834.

Moore CP, Rodney G, Zhang J-Z, Santacruz-Toloza L, Strasburg G, Hamilton SL. 1999a. Apocalmodulin and $\mathrm{Ca}^{2+}$ Calmodulin Bind to the Same Region on the Skeletal Muscle $\mathrm{Ca}^{2+}$ Release Channel. Biochemistry 38: 8532-8537. 
J.T. Lanner et al.

Mouton J, Marty I, Villaz M, Feltz A, Maulet Y. 2001. Molecular interaction of dihydropyridine receptors with type-1 ryanodine receptors in rat brain. Biochem J 354: 597-603.

Nakai J, Imagawa T, Hakamata Y, Shigekawa M, Takeshima H, Numa S. 1990. Primary structure and functional expression from cDNA of the cardiac ryanodine receptor/calcium release channel. FEBS letters 271: 169-177.

Nakai J, Sekiguchi N, Rando TA, Allen PD, Beam KG. 1998. Two regions of the ryanodine receptor involved in coupling with L-type $\mathrm{Ca}^{2+}$ channels. J Biol Chem 273: 13403-13406.

Nakanishi S, Kuwajima G, Mikoshiba K. 1992. Immunohistochemical localization of ryanodine receptors in mouse central nervous system. Neurosci Res 15: 130-142.

Neef S, Dybkova N, Sossalla S, Ort KR, Fluschnik N, Neumann K, Seipelt R, Schondube FA, Hasenfuss G, Maier LS. 2010. CaMKII-Dependent Diastolic SR $\mathrm{Ca}^{2+}$ Leak and Elevated Diastolic $\mathrm{Ca}^{2+}$ Levels in Right Atrial Myocardium of Patients with Atrial Fibrillation. Circ Res 106: $1134-1144$.

Neylon CB, Richards SM, Larsen MA, Agrotis A, Bobik A. 1995. Multiple types of ryanodine receptor $/ \mathrm{Ca}^{2+}$ release channels are expressed in vascular smooth muscle. Biochem Biophys Res Commun 215: 814-821.

Nixon GF, Mignery GA, Somlyo AV. 1994. Immunogold localization of inositol 1,4,5-trisphosphate receptors and characterization of ultrastructural features of the sarcoplasmic reticulum in phasic and tonic smooth muscle. J Muscle Res Cell Motil 15: 682-700.

O’Brien J, Meissner G, Block BA. 1993. The fastest contracting muscles of nonmammalian vertebrates express only one isoform of the ryanodine receptor. Biophys $J$ 65: 2418-2427.

Ohrtman J, Ritter B, Polster A, Beam KG, Papadopoulos S. 2008. Sequence Differences in the IQ Motifs of $\mathrm{Ca}_{\mathrm{V}} 1.1$ and $\mathrm{Ca}_{\mathrm{V}} 1.2$ Strongly Impact Calmodulin Binding and Calcium-dependent Inactivation. $J$ Biol Chem 283: 29301-29311.

Orlova EV, Serysheva II, van Heel M, Hamilton SL, Chiu W. 1996. Two structural configurations of the skeletal muscle calcium release channel. Nat Struct Mol Biol 3: 547-552.

Otsu K, Willard HF, Khanna VK, Zorzato F, Green NM, MacLennan DH. 1990. Molecular cloning of cDNA encoding the $\mathrm{Ca}^{2+}$ release channel (ryanodine receptor) of rabbit cardiac muscle sarcoplasmic reticulum. J Biol Chem 265: 13472-13483.

Ottini L, Marziali G, Conti A, Charlesworth A, Sorrentino V. 1996. Alpha and beta isoforms of ryanodine receptor from chicken skeletal muscle are the homologues of mammalian RyR1 and RyR3. Biochem J 315: 207-216.

Oyamada H, Murayama T, Takagi T, Iino M, Iwabe N, Miyata T, Ogawa Y, Endo M. 1994. Primary structure and distribution of ryanodine-binding protein isoforms of the bullfrog skeletal muscle. J Biol Chem 269: 17206-17214.

Pamukcoglu T. 1988. Sudden death due to malignant hyperthermia. Am J Forensic Med Pathol 9: 161-162.

Paolini C, Fessenden JD, Pessah IN, Franzini-Armstrong C. 2004. Evidence for conformational coupling between two calcium channels. Proc Natl Acad Sci 101: 12748-12752.
Paul-Pletzer K, Yamamoto T, Bhat MB, Ma J, Ikemoto N, Jimenez LS, Morimoto H, Williams PG, Parness J. 2002. Identification of a Dantrolene-binding Sequence on the Skeletal Muscle Ryanodine Receptor. J Biol Chem 277: 34918-34923.

Perez CF, Mukherjee S, Allen PD. 2003. Amino acids 1-1,680 of ryanodine receptor type 1 hold critical determinants of skeletal type for excitation-contraction coupling. Role of divergence domain D2. J Biol Chem 278: 39644-39652.

Phillips MS, Khanna VK, De Leon S, Frodis W, Britt BA, MacLennan DH. 1994. The substitution of Arg for Gly2433 in the human skeletal muscle ryanodine receptor is associated with malignant hyperthermia. Hum Mol Genet 3: 2181-2186.

Postma AV, Denjoy I, Hoorntje TM, Lupoglazoff JM, Da Costa A, Sebillon P, Mannens MM, Wilde AA, Guicheney P. 2002. Absence of calsequestrin 2 causes severe forms of catecholaminergic polymorphic ventricular tachycardia. Circ Res 91: e21-e26.

Priori SG, Napolitano C, Memmi M, Colombi B, Drago F, Gasparini M, DeSimone L, Coltorti F, Bloise R, Keegan $\mathrm{R}$, et al. 2002. Clinical and molecular characterization of patients with catecholaminergic polymorphic ventricular tachycardia. Circulation 106: 69-74.

Proenza C, O’Brien J, Nakai J, Mukherjee S, Allen PD, Beam KG. 2002. Identification of a Region of RyR1 That Participates in Allosteric Coupling with the $\alpha 1 S$ (CaV1.1) II-III Loop. J Biol Chem 277: 6530-6535.

Protasi F, Franzini-Armstrong C, Allen PD. 1998. Role of Ryanodine Receptors in the Assembly of Calcium Release Units in Skeletal Muscle. J Cell Biol 140: 831-842.

Protasi F, Paolini C, Nakai J, Beam KG, Franzini-Armstrong C, Allen PD. 2002. Multiple Regions of RyR1 Mediate Functional and Structural Interactions with $\alpha 1 S$ Dihydropyridine Receptors in Skeletal Muscle. Biophys J 83: $3230-3244$.

Qi Y, Ogunbunmi EM, Freund EA, Timerman AP, Fleischer S. 1998. FK-binding Protein Is Associated with the Ryanodine Receptor of Skeletal Muscle in Vertebrate Animals. J Biol Chem 273: 34813-34819.

Quane KA, Keating KE, Healy JM, Manning BM, Krivosic-Horber R, Krivosic I, Monnier N, Lunardi J, McCarthy TV. 1994. Mutation screening of the RYR1 gene in malignant hyperthermia: detection of a novel Tyr to Ser mutation in a pedigree with associated central cores. Genomics 23: 236-239.

Quinn KE, Castellani L, Ondrias K, Ehrlich BE. 1998. Characterization of the ryanodine receptor/channel of invertebrate muscle. Am J Physiol 274: R494-R502.

Radermacher M, Rao V, Grassucci R, Frank J, Timerman AP, Fleischer S, Wagenknecht T. 1994. Cryo-electron microscopy and three-dimensional reconstruction of the calcium release channel/ryanodine receptor from skeletal muscle. J Cell Biol 127: 411-423.

Radermacher M, Wagenknecht T, Grassucci R, Frank J, Inui M, Chadwick C, Fleischer S. 1992. Cryo-EM of the native structure of the calcium release channel/ryanodine receptor from sarcoplasmic reticulum. Biophys $J$ 61: 936-940.

Reiken S, Lacampagne A, Zhou H, Kherani A, Lehnart SE, Ward C, Huang F, Gaburjakova M, Gaburjakova J, Rosemblit N, et al. 2003. PKA phosphorylation activates the 
calcium release channel (ryanodine receptor) in skeletal muscle: defective regulation in heart failure. J Cell Biol 160: 919-928.

Rios E, Brum G. 1987. Involvement of dihydropyridine receptors in excitation-contraction coupling in skeletal muscle. Nature 325: 717-720.

Robinson R, Carpenter D, Shaw MA, Halsall J, Hopkins P. 2006. Mutations in RYR1 in malignant hyperthermia and central core disease. Hum Mutat 27: 977-989.

Rodney GG, Williams BY, Strasburg GM, Beckingham K, Hamilton SL. 2000. Regulation of RYR1 activity by $\mathrm{Ca}^{2+}$ and calmodulin. Biochem 39: 7807-7812.

Rodriguez P, Bhogal MS, Colyer J. 2003. Stoichiometric Phosphorylation of Cardiac Ryanodine Receptor on Serine 2809 by Calmodulin-dependent Kinase II and Protein Kinase A. J Biol Chem 278: 38593-38600.

Rosenberg H, Davis M, James D, Pollock N, Stowell K. 2007. Malignant hyperthermia. Orphanet J Rare Dis 2: 21.

Ryan JF, Tedeschi LG. 1997. Sudden unexplained death in a patient with a family history of malignant hyperthermia. J Clin Anesth 9: 66-68.

Sabbadini RA, Betto R, Teresi A, Fachechi-Cassano G, Salviati G. 1992. The effects of sphingosine on sarcoplasmic reticulum membrane calcium release. J Biol Chem 267: 15475-15484.

Samsó M, Wagenknecht T. 2002. Apocalmodulin and $\mathrm{Ca}^{2+}$. Calmodulin Bind to Neighboring Locations on the Ryanodine Receptor. J Biol Chem 277: 1349-1353.

Samsó M, Shen X, Allen PD. 2006. Structural Characterization of the RyR1-FKBP12 Interaction. J Mol Biol 356: 917-927.

Samsó M, Wagenknecht T, Allen PD. 2005. Internal structure and visualization of transmembrane domains of the RyR1 calcium release channel by cryo-EM. Nat Struct Mol Biol 12: 539-544.

Samsó M, Feng W, Pessah IN, Allen PD. 2009. Coordinated Movement of Cytoplasmic and Transmembrane Domains of RyR1 upon Gating. PLoS Biol 7: e1000085.

Scacheri PC, Hoffman EP, Fratkin JD, Semino-Mora C, Senchak A, Davis MR, Laing NG, Vedanarayanan V, Subramony SH. 2000. A novel ryanodine receptor gene mutation causing both cores and rods in congenital myopathy. Neurology 55: 1689-1696.

Schwab Y, Mouton J, Chasserot-Golaz S, Marty I, Maulet Y, Jover E. 2001. Calcium-dependent translocation of synaptotagmin to the plasma membrane in the dendrites of developing neurones. Brain Res Mol Brain Res 96: $1-13$.

Serysheva I, Hamilton S, Chiu W, Ludtke S. 2005. Structure of $\mathrm{Ca}^{2+}$ release channel at $14 \AA$ resolution. J Mol Biol 345: 427-431.

Serysheva II, Ludtke SJ, Baker ML, Cong Y, Topf M, Eramian D, Sali A, Hamilton SL, Chiu W. 2008. Subnanometer-resolution electron cryomicroscopy-based domain models for the cytoplasmic region of skeletal muscle RyR channel. Proc Natl Acad Sci 105: 9610-9615.

Serysheva II, Orlova EV, Chiu W, Sherman MB, Hamilton SL, Heel Mv. 1995. Electron cryomicroscopy and angular reconstitution used to visualize the skeletal muscle calcium release channel. Nat Struct Mol Biol 2: 18-24.
Serysheva II, Schatz M, van Heel M, Chiu W, Hamilton SL. 1999. Structure of the Skeletal Muscle Calcium Release Channel Activated with $\mathrm{Ca}^{2+}$ and AMP-PCP. Biophys $J$ 77: 1936-1944.

Sharma MR. 2006. Three-Dimensional Visualization of FKBP12.6 Binding to an Open Conformation of Cardiac Ryanodine Receptor. Biophys J 90: 164-172.

Sharma MC, Gulati S, Sarkar C, Jain D, Kalra V, Suri V. 2007. Multi-minicore disease: a rare form of myopathy. Neurol India 55: 50-53.

Sharma MR, Jeyakumar LH, Fleischer S, Wagenknecht T. 2000. Three-dimensional Structure of Ryanodine Receptor Isoform Three in Two Conformational States as Visualized by Cryo-electron Microscopy. J Biol Chem 275: 9485-9491.

Sharma MR, Penczek P, Grassucci R, Xin H-B, Fleischer S, Wagenknecht T. 1998. Cryoelectron Microscopy and Image Analysis of the Cardiac Ryanodine Receptor. J Biol Chem 273: 18429-18434.

Sharp AH, McPherson PS, Dawson TM, Aoki C, Campbell KP, Snyder SH. 1993. Differential immunohistochemical localization of inositol 1,4,5-trisphosphate- and ryanodine-sensitive $\mathrm{Ca}^{2+}$ release channels in rat brain. J Neurosci 13: 3051-3063.

Sheridan DC, Cheng W, Ahern CA, Mortenson L, Alsammarae D, Vallejo P, Coronado R. 2003. Truncation of the Carboxyl Terminus of the Dihydropyridine Receptor $\beta 1$ a Subunit Promotes $\mathrm{Ca}^{2+}$ Dependent ExcitationContraction Coupling in Skeletal Myotubes. Biophys J 84: 220-237.

Sheridan DC, Takekura H, Franzini-Armstrong C, Beam KG, Allen PD, Perez CF. 2006. Bidirectional signaling between calcium channels of skeletal muscle requires multiple direct and indirect interactions. Proc Natl Acad Sci 103: 19760-19765.

Shou W, Aghdasi B, Armstrong DL, Guo Q, Bao S, Charng M-J, Mathews LM, Schneider MD, Hamilton SL, Matzuk MM. 1998. Cardiac defects and altered ryanodine receptor function in mice lacking FKBP12. Nature 391: 489-492.

Shuaib A, Paasuke RT, Brownell KW. 1987. Central core disease. Clinical features in 13 patients. Medicine (Baltimore) 66: 389-396.

Sitsapesan R, Williams AJ. 1995. The gating of the sheep skeletal sarcoplasmic reticulum $\mathrm{Ca}^{2+}$-release channel is regulated by luminal $\mathrm{Ca}^{2+}$. J Membr Biol 146: 133-144.

Slavik KJ, Wang JP, Aghdasi B, Zhang JZ, Mandel F, Malouf N, Hamilton SL. 1997. A carboxy-terminal peptide of the alpha 1-subunit of the dihydropyridine receptor inhibits $\mathrm{Ca}^{2+}$-release channels. Am J Physiol Cell Physiol 272: C1475-C1481.

Smith JS. 1986. Single-channel calcium and barium currents of large and small conductance from sarcoplasmic reticulum. Biophys J 50: 921-928.

Smith JS, Coronado R, Meissner G. 1985. Sarcoplasmic reticulum contains adenine nucleotide-activated calcium channels. Nature 316: 446-449.

Smith J, Coronado R, Meissner G. 1986. Single channel measurements of the calcium release channel from skeletal muscle sarcoplasmic reticulum. Activation by $\mathrm{Ca}^{2+}$ and ATP and modulation by $\mathrm{Mg}^{2+}$. J Gen Physiol 88: 573-588. 
J.T. Lanner et al.

Stoyanovsky D, Murphy T, Anno PR, Kim YM, Salama G. 1997. Nitric oxide activates skeletal and cardiac ryanodine receptors. Cell Calcium 21: 19-29.

Strazis KP, Fox AW. 1993. Malignant hyperthermia: a review of published cases. Anesthesia Analgesia 77: 297-304.

Sun J, Xin C, Eu JP, Stamler JS, Meissner G. 2001 Cysteine-3635 is responsible for skeletal muscle ryanodine receptor modulation by NO. Proc Natl Acad Sci 98: 11158-11162.

Sun J, Yamaguchi N, Xu L, Eu JP, Stamler JS, Meissner G. 2008. Regulation of the Cardiac Muscle Ryanodine Receptor by $\mathrm{O}_{2}$ Tension and S-Nitrosoglutathion. Biochemistry 47: 13985-13990.

Supnet C, Noonan C, Richard K, Bradley J, Mayne M. 2009. Up-regulation of the type 3 ryanodine receptor is neuroprotective in the TgCRND8 mouse model of Alzheimer's disease. J Neurochem 112: 356-265.

Takasago T, Imagawa T, Shigekawa M. 1989. Phosphorylation of the Cardiac Ryanodine Receptor by cAMPDependent Protein Kinase. J Biochem 106: 872-877.

Takekura H, Sun X, Franzini-Armstrong C. 1994. Development of the excitation-contraction coupling apparatus in skeletal muscle: peripheral and internal calcium release units are formed sequentially. J Muscle Res Cell Motility 15: $102-118$.

Takeshima H, Nishi M, Iwabe N, Miyata T, Hosoya T, Masai I, Hotta Y. 1994. Isolation and characterization of a gene for a ryanodine receptor/calcium release channel in Drosophila melanogaster. FEBS Lett 337: 81-87.

Takeshima H, Nishimura S, Matsumoto T, Ishida H, Kangawa K, Minamino N, Matsuo H, Ueda M, Hanaoka M, Hirose T, et al. 1989. Primary structure and expression from complementary DNA of skeletal muscle ryanodine receptor. Nature 339: 439-445.

Tanabe T, Beam KG, Adams BA, Niidome T, Numa S. 1990 Regions of the skeletal muscle dihydropyridine receptor critical for excitation-contraction coupling. Nature 346: 567-569.

Tang W, Sencer S, Hamilton SL. 2002. Calmodulin modulation of proteins involved in excitation-contraction coupling. Frontiers Biosci 7: d1583-1589.

Tang W, Ingalls CP, Durham WJ, Snider J, Reid MB, Wu G, Matzuk MM, Hamilton SL. 2004. Altered excitationcontraction coupling with skeletal muscle specific FKBP12 deficiency. FASEB J: 04-1587fje.

Tilgen N, Zorzato F, Halliger-Keller B, Muntoni F, Sewry C, Palmucci LM, Schneider C, Hauser E, Lehmann-Horn F, Muller CR, et al. 2001. Identification of four novel mutations in the C-terminal membrane spanning domain of the ryanodine receptor 1: association with central core disease and alteration of calcium homeostasis. Hum Mol Genet 10: 2879-2887.

Timerman AP, Ogunbumni E, Freund E, Wiederrecht G, Marks AR, Fleischer S. 1993. The calcium release channel of sarcoplasmic reticulum is modulated by FK-506binding protein. Dissociation and reconstitution of FKBP-12 to the calcium release channel of skeletal muscle sarcoplasmic reticulum. J Biol Chem 268: 22992-22999.

Timerman AP, Onoue H, Xin H-B, Barg S, Copello J, Wiederrecht G, Fleischer S. 1996. Selective Binding of
FKBP12.6 by the Cardiac Ryanodine Receptor. J Biol Chem 271: 20385-20391.

Timerman AP, Wiederrecht G, Marcy A, Fleischer S. 1995. Characterization of an Exchange Reaction between Soluble FKBP-12 and the FKBP Ryanodine Receptor Complex. J Biol Chem 270: 2451-2459.

Tiso N, Stephan DA, Nava A, Bagattin A, Devaney JM, Stanchi F, Larderet G, Brahmbhatt B, Brown K, Bauce $\mathrm{B}$, et al. 2001. Identification of mutations in the cardiac ryanodine receptor gene in families affected with arrhythmogenic right ventricular cardiomyopathy type 2 (ARVD2). Hum Mol Genet 10: 189-194.

Tong J, McCarthy TV, MacLennan DH. 1999. Measurement of resting cytosolic $\mathrm{Ca}^{2+}$ concentrations and $\mathrm{Ca}^{2+}$ store size in HEK-293 cells transfected with malignant hyperthermia or central core disease mutant $\mathrm{Ca}^{2+}$ release channels. J Biol Chem 274: 693-702.

Tripathy A, Xu L, Mann G, Meissner G. 1995. Calmodulin activation and inhibition of skeletal muscle $\mathrm{Ca}^{2+}$ release channel (ryanodine receptor). Biophy J 69: 106-119.

Tunwell RE, Wickenden C, Bertrand BM, Shevchenko VI, Walsh MB, Allen PD, Lai FA. 1996. The human cardiac muscle ryanodine receptor-calcium release channel: identification, primary structure and topological analysis. Biochem J 318: 477-487.

Valdivia HH. 2007. One gene, many proteins: alternative splicing of the ryanodine receptor gene adds novel functions to an already complex channel protein. Circ Res 100: 761-763.

Valdivia HH, Kaplan JH, Ellis-Davies GCR, Lederer WJ. 1995. Rapid Adaptation of Cardiac Ryanodine Receptors: Modulation by $\mathrm{Mg}^{2+}$ and Phosphorylation. Science 267: 1997-2000.

Vazquez-Martinez O, Canedo-Merino R, Diaz-Muñoz M, Riesgo-Escovar JR. 2003. Biochemical characterization, distribution and phylogenetic analysis of Drosophila melanogaster ryanodine and IP3 receptors, and thapsigargin-sensitive $\mathrm{Ca}^{2+}$ ATPase. Journal of Cell Science 116: $2483-2494$.

Voss AA, Lango J, Ernst-Russell M, Morin D, Pessah IN. 2004. Identification of Hyperreactive Cysteines within Ryanodine Receptor Type 1 by Mass Spectrometry. J Biol Chem 279: 34514-34520.

Vukcevic M, Broman M, Islander G, Bodelsson M, Ranklev-Twetman E, Müller CR, Treves S. 2010. Functional Properties of RYR1 Mutations Identified in Swedish Patients with Malignant Hyperthermia and Central Core Disease. Anesthesia \& Analgesia 111: 185-190.

Wagenknecht T, Berkowitz J, Grassucci R, Timerman AP, Fleischer S. 1994. Localization of calmodulin binding sites on the ryanodine receptor from skeletal muscle by electron microscopy. Biophys J 67: 2286-2295.

Wagenknecht T, Grassucci R, Berkowitz J, Wiederrecht GJ, Xin HB, Fleischer S. 1996. Cryoelectron microscopy resolves FK506-binding protein sites on the skeletal muscle ryanodine receptor. Biophys J 70: 1709-1715.

Wagenknecht T, Radermacher M, Grassucci R, Berkowitz J, Xin H-B, Fleischer S. 1997. Locations of Calmodulin and FK506-binding Protein on the Three-dimensional Architecture of the Skeletal Muscle Ryanodine Receptor. J Biol Chem 272: 32463-32471. 
Wang J, Best PM. 1992. Inactivation of the sarcoplasmic reticulum calcium channel by protein kinase. Nature 359: 739-741.

Wang R, Chen W, Cai S, Zhang J, Bolstad J, Wagenknecht T, Liu Z, Chen SRW. 2007. Localization of an NH2terminal Disease-causing Mutation Hot Spot to the "Clamp"? Region in the Three-dimensional Structure of the Cardiac Ryanodine Receptor. J Biol Chem 282: 17785-17793.

Ward A, Chaffman M, Sorkin E. 1986. Dantrolene. A review of its pharmacodynamic and pharmacokinetic properties and therapeutic use in malignant hyperthermia, the neuroleptic malignant syndrome and an update of its use in muscle spasticity. Drugs 32: 130-168.

Wehrens XH, Marks AR. 2003. Altered function and regulation of cardiac ryanodine receptors in cardiac disease. Trends Biochem Sci 28: 671-678.

Wehrens XH, Lehnart SE, Huang F, Vest JA, Reiken SR, Mohler PJ, Sun J, Guatimosim S, Song LS, Rosemblit $\mathrm{N}$, et al. 2003. FKBP12.6 deficiency and defective calcium release channel (ryanodine receptor) function linked to exercise-induced sudden cardiac death. Cell 113: 829-840.

Wehrens XHT, Lehnart SE, Reiken SR, Marks AR. 2004 $\mathrm{Ca}^{2+} /$ Calmodulin-Dependent Protein Kinase II Phosphorylation Regulates the Cardiac Ryanodine Receptor. Circ Res 94: e61-e70.

Wei L, Hanna AD, Beard NA, Dulhunty AF. 2009. Unique isoform-specific properties of calsequestrin in the heart and skeletal muscle. Cell Calcium 45: 474-484.

Witcher DR, Kovacs RJ, Schulman H, Cefali DC, Jones LR. 1991. Unique phosphorylation site on the cardiac ryanodine receptor regulates calcium channel activity. J Biol Chem 266: 11144-11152.

Wright NT, Prosser BL, Varney KM, Zimmer DB, Schneider MF, Weber DJ. 2008. S100A1 and Calmodulin Compete for the Same Binding Site on Ryanodine Receptor. $J$ Biol Chem 283: 26676-26683.

Xiao B, Jiang MT, Zhao M, Yang D, Sutherland C, Lai FA, Walsh MP, Warltier DC, Cheng H, Chen SRW. 2005. Characterization of a Novel PKA Phosphorylation Site, Serine-2030, Reveals No PKA Hyperphosphorylation of the Cardiac Ryanodine Receptor in Canine Heart Failure. Circ Res 96: 847-855.

Xiao B, Sutherland C, Walsh MP, Chen SRW. 2004 Protein Kinase A Phosphorylation at Serine-2808 of the Cardiac $\mathrm{Ca}^{2+}$-Release Channel (Ryanodine Receptor) Does Not Dissociate 12.6-kDa FK506-Binding Protein (FKBP12.6). Circ Res 94: 487-495.

Xiao B, Zhong G, Obayashi M, Yang D, Chen K, Walsh MP, Shimoni Y, Cheng H, Ter Keurs H, Chen SRW. 2006. Ser-2030, but not Ser-2808, is the major phosphorylation site in cardiac ryanodine receptors responding to protein kinase $A$ activation upon $\beta$-adrenergic stimulation in normal and failing hearts. Biochem J 396: 7-16.

Xu L, Mann G, Meissner G. 1996. Regulation of Cardiac $\mathrm{Ca}^{2+}$ Release Channel (Ryanodine Receptor) by $\mathrm{Ca}^{2+}$, $\mathrm{H}^{+}, \mathrm{Mg}^{2+}$, and Adenine Nucleotides Under Normal and Simulated Ischemic Conditions. Circ Res 79: $1100-$ 1109.

Xu L, Eu JP, Meissner G, Stamler JS. 1998. Activation of the cardiac calcium release channel (ryanodine receptor) by poly-S-nitrosylation. Science 279: 234-237.
Xu X, Yano M, Uchinoumi H, Hino A, Suetomi T, Ono M, Tateishi H, Oda T, Okuda S, Doi M, et al. 2010. Defective calmodulin binding to the cardiac ryanodine receptor plays a key role in CPVT-associated channel dysfunction. Biochemical and Biophysical Research Communications 394: 660-666.

Yamaguchi N, Xu L, Pasek DA, Evans KE, Chen SRW, Meissner G. 2005. Calmodulin Regulation and Identification of Calmodulin Binding Region of Type-3 Ryanodine Receptor Calcium Release Channel. Biochemistry 44: 15074-15081.

Yamaguchi N, Xu L, Pasek DA, Evans KE, Meissner G. 2003. Molecular Basis of Calmodulin Binding to Cardiac Muscle $\mathrm{Ca}^{2+}$ Release Channel (Ryanodine Receptor). J Biol Chem: 23480-23486.

Yang HC, Reedy MM, Burke CL, Strasburg GM. 1994. Calmodulin interaction with the skeletal muscle sarcoplasmic reticulum calcium channel protein. Biochemistry 33: $518-525$.

Zable AC, Favero TG, Abramson JJ. 1997. Glutathione modulates ryanodine receptor from skeletal muscle sarcoplasmic reticulum. Evidence for redox regulation of the $\mathrm{Ca}^{2+}$ release mechanism. J Biol Chem 272: 7069-7077.

Zaidi M, Shankar VS, Towhidul Alam AS, Moonga BS, Pazianas M, Huang CL. 1992. Evidence that a ryanodine receptor triggers signal transduction in the osteoclast. Biochemical and Biophysical Research Communications 188: $1332-1336$.

Zhang Y, Chen HS, Khanna VK, De Leon S, Phillips MS, Schappert K, Britt BA, Browell AK, MacLennan DH. 1993. A mutation in the human ryanodine receptor gene associated with central core disease. Nat Genet 5: 46-50.

Zhang J, Liu Z, Masumiya H, Wang R, Jiang D, Li F, Wagenknecht T, Chen SRW. 2003. Three-dimensional Localization of Divergent Region 3 of the Ryanodine Receptor to the Clamp-shaped Structures Adjacent to the FKBP Binding Sites. J Biol Chem 278: 14211-14218.

Zhao F, Li P, Chen SRW, Louis CF, Fruen BR. 2001. Dantrolene Inhibition of Ryanodine Receptor $\mathrm{Ca}^{2+}$ Release Channels. J Biol Chem 276: 13810-13816.

Zhao M, Li P, Li X, Zhang L, Winkfein RJ, Chen SRW. 1999. Molecular Identification of the Ryanodine Receptor Pore-forming Segment. J Biol Chem 274: 25971-25974.

Zhou H, Lillis S, Loy RE, Ghassemi F, Rose MR, Norwood F, Mills K, Al-Sarraj S, Lane RJ, Feng L, et al. 2010. Multi-minicore disease and atypical periodic paralysis associated with novel mutations in the skeletal muscle ryanodine receptor (RYR1) gene. Neuromuscul Disord 20: $166-173$.

Zissimopoulos S, Lai FA. 2005. Interaction of FKBP12.6 with the Cardiac Ryanodine Receptor C-terminal Domain. J Biol Chem 280: 5475-5485.

Zorzato F, Fujii J, Otsu K, Phillips M, Green NM, Lai FA, Meissner G, MacLennan DH. 1990. Molecular cloning of cDNA encoding human and rabbit forms of the $\mathrm{Ca}^{2+}$ release channel (ryanodine receptor) of skeletal muscle sarcoplasmic reticulum. J Biol Chem 265: 2244-2256. 


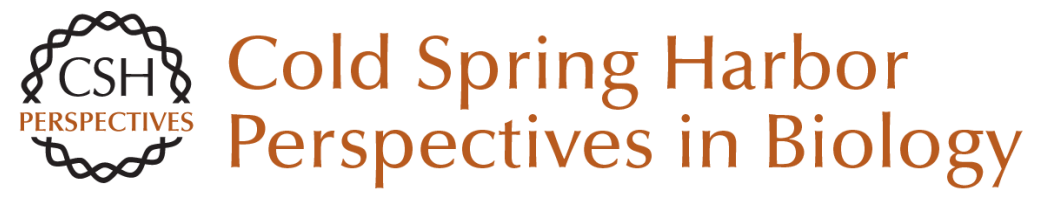

\section{Ryanodine Receptors: Structure, Expression, Molecular Details, and Function in Calcium Release}

Johanna T. Lanner, Dimitra K. Georgiou, Aditya D. Joshi and Susan L. Hamilton

Cold Spring Harb Perspect Biol 2010; doi: 10.1101/cshperspect.a003996 originally published online October 20, 2010

\section{Subject Collection Calcium Signaling}

The Endoplasmic Reticulum-Plasma Membrane Junction: A Hub for Agonist Regulation of $\mathrm{Ca}^{2+}$ Entry

Hwei Ling Ong and Indu Suresh Ambudkar

Calcium-Handling Defects and Neurodegenerative

Disease

Sean Schrank, Nikki Barrington and Grace E. Stutzmann

Lysosomal $\mathrm{Ca}^{2+}$ Homeostasis and Signaling in Health and Disease

Emyr Lloyd-Evans and Helen Waller-Evans

$\mathrm{Ca}^{2+}$ Signaling in Exocrine Cells

Malini Ahuja, Woo Young Chung, Wei-Yin Lin, et al.

Functional Consequences of Calcium-Dependent Synapse-to-Nucleus Communication: Focus on Transcription-Dependent Metabolic Plasticity Anna M. Hagenston, Hilmar Bading and Carlos Bas-Orth

Identifying New Substrates and Functions for an Old Enzyme: Calcineurin

Jagoree Roy and Martha S. Cyert

Fundamentals of Cellular Calcium Signaling: A

Primer

Martin D. Bootman and Geert Bultynck
Primary Active $\mathrm{Ca}^{2+}$ Transport Systems in Health and Disease

Jialin Chen, Aljona Sitsel, Veronick Benoy, et al.

Signaling through $\mathrm{Ca}^{2+}$ Microdomains from

Store-Operated CRAC Channels

Pradeep Barak and Anant B. Parekh

Structural Insights into the Regulation of $\mathrm{Ca}^{2+}$ /Calmodulin-Dependent Protein Kinase II (CaMKII) Moitrayee Bhattacharyya, Deepti Karandur and John Kuriyan

Store-Operated Calcium Channels: From Function to Structure and Back Again Richard S. Lewis

Bcl-2-Protein Family as Modulators of $\mathrm{IP}_{3}$

Receptors and Other Organellar $\mathrm{Ca} 2+$ Channels Hristina Ivanova, Tim Vervliet, Giovanni Monaco, et al.

Calcium Signaling in Cardiomyocyte Function Guillaume Gilbert, Kateryna Demydenko, Eef Dries, et al.

Cytosolic $\mathrm{Ca}^{2+}$ Buffers Are Inherently $\mathrm{Ca}^{2+}$ Signal Modulators Beat Schwaller

For additional articles in this collection, see http://cshperspectives.cshlp.org/cgi/collection/

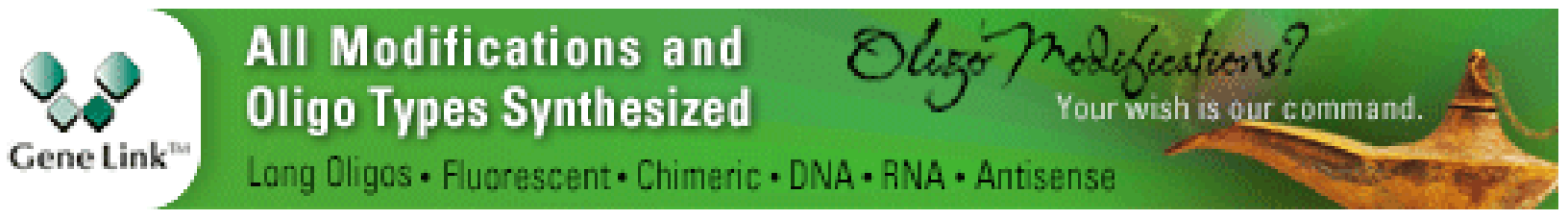


Role of Two-Pore Channels in Embryonic Development and Cellular Differentiation Sarah E. Webb, Jeffrey J. Kelu and Andrew L. Miller

\section{Organellar Calcium Handling in the Cellular \\ Reticular Network}

Wen-An Wang, Luis B. Agellon and Marek Michalak

For additional articles in this collection, see http://cshperspectives.cshlp.org/cgi/collection/

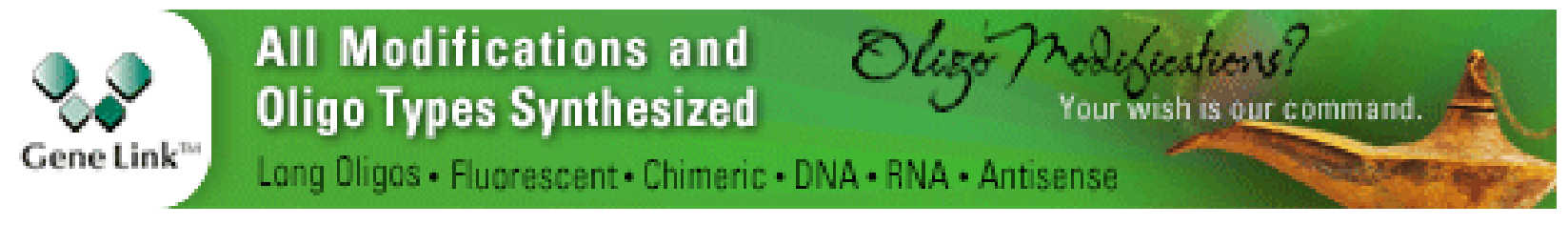

Copyright @ 2010 Cold Spring Harbor Laboratory Press; all rights reserved 